\title{
Two billion years of episodic and simultaneous websteritic and eclogitic diamond formation beneath the Orapa kimberlite cluster, Botswana
}

\author{
M. U. Gress ${ }^{1} \mathbb{C} \cdot$ S. Timmerman ${ }^{1,2} \cdot$ I. L. Chinn ${ }^{3} \cdot$ J. M. Koornneef ${ }^{1} \cdot$ E. Thomassot ${ }^{4} \cdot$ E. A. S. van der Valk ${ }^{1}$. \\ K. van Zuilen ${ }^{1} \cdot$ N. Bouden ${ }^{4}$. G. R. Davies ${ }^{1}$
}

Received: 30 December 2020 / Accepted: 3 May 2021 / Published online: 23 June 2021

(c) The Author(s) 2021

\begin{abstract}
The Sm-Nd isotope systematics and geochemistry of eclogitic, websteritic and peridotitic garnet and clinopyroxene inclusions together with characteristics of their corresponding diamond hosts are presented for the Letlhakane mine, Botswana. These data are supplemented with new inclusion data from the nearby $(20-30 \mathrm{~km})$ Orapa and Damtshaa mines to evaluate the nature and scale of diamond-forming processes beneath the NW part of the Kalahari Craton and to provide insight into the evolution of the deep carbon cycle. The $\mathrm{Sm}-\mathrm{Nd}$ isotope compositions of the diamond inclusions indicate five well-defined, discrete eclogitic and websteritic diamond-forming events in the Orapa kimberlite cluster at $220 \pm 80 \mathrm{Ma}, 746 \pm 100 \mathrm{Ma}$, $1110 \pm 64 \mathrm{Ma}, 1698 \pm 280 \mathrm{Ma}$ and $2341 \pm 21 \mathrm{Ma}$. In addition, two poorly constrained events suggest ancient eclogitic (>2700 Ma) and recent eclogitic and websteritic diamond formation (<140 Ma). Together with sub-calcic garnets from two harzburgitic diamonds that have Archaean Nd mantle model ages $\left(T_{\mathrm{CHUR}}\right)$ between 2.86 and $3.38 \mathrm{Ga}$, the diamonds studied here span almost the entire temporal evolution of the SCLM of the Kalahari Craton. The new data demonstrate, for the first time, that diamond formation occurs simultaneously and episodically in different parageneses, reflecting metasomatism of the compositionally heterogeneous SCLM beneath the area $\left(\sim 200 \mathrm{~km}^{2}\right)$. Diamond formation can be directly related to major tectono-magmatic events that impacted the Kalahari Craton such as crustal accretion, continental breakup and large igneous provinces. Compositions of dated inclusions, in combination with marked variations in the carbon and nitrogen isotope compositions of the host diamonds, record mixing arrays between a minimum of three components (A: peridotitic mantle; B: eclogites dominated by mafic material; C: eclogites that include recycled sedimentary material). Diamond formation appears dominated by local fluid-rock interactions involving different protoliths in the SCLM. Redistribution of carbon during fluid-rock interactions generally masks any potential temporal changes of the deep carbon cycle.
\end{abstract}

Keywords Diamond inclusion dating $\cdot$ Eclogite $\cdot$ Websterite $\cdot$ Pyroxenite $\cdot$ Craton $\cdot$ Carbon and nitrogen isotope

\section{Introduction}

Communicated by Dante Canil.

M. U. Gress

m.u.gress@vu.nl

1 Vrije Universiteit, De Boelelaan 1085, 1081 HV Amsterdam, The Netherlands

2 Earth and Atmospheric Sciences, University of Alberta, Edmonton T6E 2E5, Canada

3 De Beers Exploration, Private Bag X01, Southdale 2135, South Africa

4 Centre de Recherches Pétrographiques Et Géochimiques (CRPG), Université de Lorraine, 15 Rue Notre Dame des Pauvres, BP 20, 54501 Vandœuvre-lès-Nancy, France
Diamonds and incorporated inclusions allow researchers to investigate large-scale processes such as plate tectonics and crustal recycling (Farquhar et al. 2002; Gurney et al. 2010; Schulze et al. 2003; Shirey and Richardson 2011). They provide samples of Earth's otherwise inaccessible sub-continental lithospheric mantle (SCLM) and a record of deep cycling of volatile elements (Cartigny et al. 1999; Deines 1980; Howell et al. 2020; Shirey et al. 2019). Together, these observations have led to the current paradigm that diamond formation involves metasomatic processes in the mantle comprising volatile-rich, supercritical high-density fluids, possibly triggered by tectono-magmatic events (Deines 
1980; Schrauder et al. 1996; Sobolev et al. 1998; Stachel et al. 2005; Thomassot et al. 2007). Insights from diamond inclusion ages, spectroscopic observations of internal growth patterns and from the heterogeneous stable isotope compositions of diamonds worldwide have established evidence for episodic diamond growth in discrete peridotitic (P-type), eclogitic (E-type) or websteritic (W-type) parageneses (Aulbach et al. 2018; Cartigny et al. 2014; Koornneef et al. 2017; Pearson et al. 1998; Richardson et al. 2004; Smit et al. 2016; Timmerman et al. 2017; Wiggers de Vries et al. 2013).

P-type diamonds formed in highly melt-depleted, harzburgitic, residues and lherzolitic substrates (Koornneef et al. 2017; Richardson et al. 1984; Stachel et al. 2004a). Based on mineralogy and stable isotope record, several hypotheses have been proposed for the formation of E-type diamonds. In particular, they have been ascribed to subduction of oceanic lithosphere and its incorporation into the peridotitic SCLM (Deines et al. 1984; Li et al. 2019; Taylor et al. 1990), high-temperature volatile fractionation (Cartigny et al. 1998; Galimov 1991; Javoy et al. 1986) or primordial mantle heterogeneities (Deines et al. 1997). Websteritic diamonds have a transitional character with inclusion compositions similar to P-type diamonds but carbon isotopic compositions resembling E-type diamonds (Deines et al. 1997). Their formation appears to be related to re-fertilisation reactions (Bodinier et al. 2008; Smit et al. 2014; Taylor et al. 2003) through mixing of mafic, possibly slab-derived, fluids with peridotitic SCLM (Aulbach et al. 2002) or reaction with eclogites in a halo around an ascending mantle plume (Sleep 2006; Viljoen et al. 2018).

Unprecedented access to inclusion-bearing diamonds from the 93.1 Ma Orapa kimberlite cluster in north-east Botswana (Allsopp et al. 1989; Davis 1977) allows us to further examine diamond formation and the extent and timescale over which these events occurred, to place better constraints on the geological processes that lead to their formation. Recently, Timmerman et al. (2017) presented $\mathrm{Sm}-\mathrm{Nd}$ isochron ages for eclogitic silicate inclusions from Letlhakane $(245 \pm 38 \mathrm{Ma} ; 998 \pm 140 \mathrm{Ma} ; 2334 \pm 22 \mathrm{Ma})$ and Orapa $(140 \pm 93 \mathrm{Ma} ; 1096 \pm 230 \mathrm{Ma} ; 1699 \pm 340 \mathrm{Ma})$ mines that confirmed multi-stage diamond growth. Their work supported observations of Deines et al. (1993) for mixing of distinct sources comprising organic carbon $\left(\delta^{13} \mathrm{C}<-35 \%\right.$ ), carbonate sediments $\left(\delta^{13} \mathrm{C}\right.$ from $-10 \%$ to $-5 \%$ ) and depleted mantle material $\left(\delta^{13} \mathrm{C} \sim-6 \%\right.$ ) to account for the observed compositional variability in E-type diamonds.

In combination with the data from Timmerman et al. (2017), the present study examines diamonds of E-, W- and P-type paragenesis from Letlhakane (LK; $n=78$ inclusions), Orapa (OR; $n=2)$ and Damtshaa (DM; $n=2)$ mines. Overall, the Orapa cluster is known for its unusual predominance of eclogitic $(\sim 85 \%)$ over peridotitic diamonds (Deines et al. 1993; Gurney et al. 1984) and it is one of the few locations on the Kalahari Craton where a websteritic diamond suite (5\%) is present (see Viljoen et al. (2018) and references therein). Thus, in addition to new eclogitic garnet and clinopyroxene inclusion ages from the three mines, we provide the first websteritic and harzburgitic Sm-Nd ages for Letlhakane along with their major and trace element compositions. These data are set in context of the host diamond growth structure, the nitrogen content and aggregation data, as well as carbon and nitrogen isotope compositions of corresponding diamond growth zones. This approach allows assessment of whether diamond-forming processes occur simultaneously or at different times in different parageneses beneath individual mines or entire regions. These constraints are crucial for understanding the nature and style of diamond formation and the broader interpretation of the evolution of the SCLM. Details on regional geology and the major tectono-magmatic events that potentially influenced diamond formation are discussed in Online Resource 1.

\section{Materials and methods}

Run of mine production was examined from the Letlhakane Mine with diamonds ranging in size from 0.1 to 1.2 carat (sieve classes $+05,+07,+09,+11 ; 3,4$ and 5/6 grainers) at the Diamond Trading Company in Gaborone, Botswana (DTCB). In total, over 77,900 diamonds ( 21,400 carat) were characterised visually for their inclusion $(>10 \mu \mathrm{m}$ in size) content using binocular microscopes as outlined in Gress et al. (2018).

After morphological characterisation central diamond plates were cut and polished in $\{110\}$ orientation from 87 LK diamonds containing multiple large $(>50 \mu \mathrm{m})$ garnet, clinopyroxene and sulphide inclusions and these plates were photographed and imaged by cathodoluminescence (CL). Identification of kyanite and coesite was confirmed by Raman spectroscopy. Nine of the plates (LK09, LK10, LK33, LK40, LK42, LK47, LK50, LK75, LK79) were described in Timmerman et al. (2017). The inclusion-bearing diamonds from Orapa $(n=2)$ and Damtshaa $(n=2)$, for which inclusion ages and general characteristics are presented here, were selected by the same criteria from a selection of 160,000 diamonds (Gress et al. 2021).

\section{Nitrogen content and aggregation}

Infrared absorbance spectra were collected on whole diamonds during sampling at DTCB and along traverses on central plates on several FTIR instruments with different experimental settings (for more details see Gress et al. (2018) and Online Resource 1). Errors for $\mathrm{N}$ content and $\mathrm{N}$ aggregation (expressed as $\% B=100 B /[A+B]$ ) are typically $\pm 10 \%$ and $\pm 5 \%$, respectively, but uncertainties increase with plate 
thickness and decreasing $\mathrm{N}$ abundance. The significance of the $\mathrm{N}$ aggregation data with low $\mathrm{N}$ abundance is limited because $\mathrm{N}$ aggregation effectively only takes place with contents $>200$ at. ppm (Taylor et al. 1990). Therefore, the data were filtered for spectra with $<200$ at. ppm N, and N aggregation data from these samples were excluded from the figures (see Online Resource 1). The terminology used to describe diamond growth structures distinguishes major growth zones where the $\mathrm{N}$ abundance showed a variation $>100$ at. ppm (i.e., core, intermediate, rim).

\section{Carbon and nitrogen isotopes}

Carbon isotope ratios were determined from selected diamond growth zones using a large-geometry secondary ion mass spectrometer (LG-SIMS) at CRPG, Nancy, and gas source mass spectrometry (GSMS) at VU Amsterdam. For GSMS, the major growth zones were sampled from diamond fragments of about $0.05-0.1 \mathrm{mg}$ from known location within a diamond ( $n=193$ growth zones) and combusted in an element analyser, as described in Timmerman et al. (2017). These analyses are referred to as 'combustion' analyses and are expressed in delta notation relative to Vienna PeeDee Belemnite (VPDB), $\delta^{13} \mathrm{C}_{\mathrm{VPDB}}[\% o]=\left({ }^{13} \mathrm{C} /{ }^{12} \mathrm{C}_{\text {sample }} /{ }^{13} \mathrm{C} /{ }^{12}\right.$ $\left.\mathrm{C}_{\mathrm{VPDB}}-1\right) \times 10^{3}$. Reported uncertainties (Online Resource 1) were obtained from the reference materials analysed in the corresponding analytical session and yield $\pm 0.12 \%$ 。 to $\pm 0.20 \%$ o (SD). Overall, duplicates of 14 diamond growth zones were analysed in different sessions with indistinguishable data (Online Resource 2: Table ESM_2.3). For LGSIMS, a Cameca IMS-1280-h multi-collection ion microprobe equipped with high sensitivity Faradays cups (see Online Resource 1 and Bouden (2021)) measured carbon isotopes on central plates ( $n=9$ diamonds) in proximity to FTIR analyses and on polished fragments ( $n=7$ diamonds) obtained from major growth zones. Instrumental mass fractionation (IMF) was monitored using reference material Dp-418 $\left(\delta^{13} \mathrm{C}=-5.32 \% \circ\right)$, Nam-56 $\left(\delta^{13} \mathrm{C}=-29.3 \% \circ\right)$, Nam-114 $\left(\delta^{13} \mathrm{C}=-26.93 \%\right.$ ), see Cartigny et al. (2004), and give an absolute standard error of $0.14 \%$ of the entire analytical session. Long-term error propagation (i.e. for the entire session) gives uncertainties ranging from $\pm 0.15 \%$ o to $\pm 0.17 \%$ o (SD).

In-situ nitrogen content and isotopic composition were measured on polished fragments ( $n=5$ diamonds) adjacent to $\mathrm{C}$ isotope analysis locations, on the same instrument with similar settings for the primary ${ }^{133} \mathrm{Cs}+$ beam (Online Resource 1). Nitrogen isotope data are expressed in delta notation relative to air, $\delta^{15} \mathrm{~N}_{\mathrm{AIR}}[\% o]=\left({ }^{15} \mathrm{~N} /{ }^{14} \mathrm{~N}_{\text {sample }}{ }^{15} \mathrm{~N}\right.$ $\left./{ }^{14} \mathrm{~N}_{\mathrm{AIR}}-1\right) \times 10^{3}$. Uncertainties associated with counting statistics mainly depend on $\mathrm{N}$ content (decreasing uncertainties with increasing concentration), with a typical $2 \mathrm{SD}$ uncertainty of $1 \%$ in diamonds containing 500 at. ppm.
Instrumental mass fractionation was monitored after every 10 unknowns using reference material Nam-22 and Nam$114\left(\delta^{15} \mathrm{~N}=1.4 \%\right.$ and $4 \%$, respectively, see Cartigny et al. (2004)) and the long-term standard deviation by IMF is better than $0.32 \%$. Uncertainties for individual measurements range from $\pm 0.46 \%$ o to $\pm 1.73 \%$ o (SD). More details for the methods can be found in Online Resource 1 and Gress et al. (2020).

\section{Inclusion geochemistry}

Silicate inclusions were analysed for their major element composition using Jeol JXA-8800 M and Jeol JXA-8350F Electron probe microanalyzers following the method of Timmerman et al. (2015). Analyses on both instruments were conducted with $15 \mathrm{kV}$ accelerating voltage, $25 \mathrm{nA}$ beam current, and $1 \mu \mathrm{m}$ beam size. After EPMA analyses (Online Resource 2: Table ESM_2.4), the inclusions were washed in ethanol, deionised and Milli-Q water to remove the carbon coating prior to spiking and digesting the inclusions for trace element and isotopic analysis. The detailed procedures are described in Online Resource 1; all corresponding data are provided in Online Resource 2: Tables ESM_2.5 and ESM_2.6.

Following chromatography, all matrix fractions were merged and dried down for trace element analyses on a Thermo X-Series II. Samarium and neodymium isotope compositions and concentrations were measured on a Thermo Scientific Triton Plus fitted with four $10^{13} \Omega$ amplifiers. The $\mathrm{Rb}, \mathrm{Sr}, \mathrm{Sm}$, and $\mathrm{Nd}$ measurements follow the set-up described in Timmerman et al. (2017) and Gress et al. (2020). Standards yielded average values of ${ }^{87} \mathrm{Rb} /{ }^{85} \mathrm{Rb}$ of $0.38525 \pm 0.00467$ ( $n=9$; NBS984 $0.05 \mathrm{ng}),{ }^{87} \mathrm{Sr} /{ }^{86} \mathrm{Sr}$ of $0.710247 \pm 0.000013(n=9$; NBS987 $0.2 \mathrm{ng})$ and $0.710250 \pm 0.000009(n=9 ; \mathrm{NBS} 987200 \mathrm{ng})$, ${ }^{143} \mathrm{Nd} /{ }^{144} \mathrm{Nd}$ of $0.511333 \pm 0.000027 \quad(n=7$; CIGO $0.1 \mathrm{ng}), 0.512100 \pm 0.000013(n=7$; JNdI $200 \mathrm{ng})$ and $0.516817 \pm 0.000023$ for $20 \mathrm{ng} \mathrm{Sm}$-std $(n=9)$. All concentrations and isotopic compositions were blank corrected using previously determined blank $\mathrm{Sr}$ and $\mathrm{Nd}$ isotope compositions (Timmerman et al. 2017). Overall, blanks were $0.44 \pm 0.14 \mathrm{pg}(n=12 ; 2 \mathrm{SE})$ for $\mathrm{Rb}, 15.0 \pm 4.8 \mathrm{pg}(n=13)$ for Sr, $0.14 \pm 0.15 \mathrm{pg}(n=11)$ for $\mathrm{Sm}$, and $0.6 \pm 0.6 \mathrm{pg}(n=13)$ for Nd (Online Resource 1).

\section{Results}

On average, $3.4 \%$ of the 77,900 diamonds at Letlhakane are inclusion-bearing (Table 1). Sulphide inclusions are the most abundant ( 81\%), followed by eclogitic silicate (6.6\%), unidentified silicate $(5.1 \%)$ and peridotitic silicate $(3.1 \%)$ inclusions. Diamonds with combined eclogitic silicate and 
Table 1 Inclusion abundance at Letlhakane

\begin{tabular}{|c|c|c|c|c|c|c|c|c|c|}
\hline \multirow{2}{*}{$\begin{array}{l}\text { DTC } \\
\text { sieve } \\
\text { class }\end{array}$} & \multirow[t]{2}{*}{ Lot } & \multirow{2}{*}{$\begin{array}{l}\text { Dia- } \\
\text { monds }\end{array}$} & \multicolumn{3}{|c|}{ Silicates [\%] } & \multicolumn{2}{|c|}{ Sulphides [\%] } & \multirow{2}{*}{$\begin{array}{l}\text { Eclogitic } \\
\text { silicates and } \\
\text { sulphides [\%] }\end{array}$} & \multirow{2}{*}{$\begin{array}{l}\text { Total } \\
\text { inclusions }{ }^{\mathrm{b}} \\
{[\%]}\end{array}$} \\
\hline & & & $E$ & $P$ & UN & Single & Multiple & & \\
\hline+07 & LK40D & 10,700 & 7.7 & 5.3 & 11.5 & 29.3 & 46.2 & - & 1.9 \\
\hline$+09^{a}$ & LK40D & 13,500 & - & - & - & - & - & - & - \\
\hline+11 & LK40D & 6,800 & 4.7 & 1.2 & 7.1 & 39.4 & 47.6 & - & 2.5 \\
\hline $3 \mathrm{Gr}^{\mathrm{a}}$ & LK40D & 2,500 & 3.4 & 1.4 & 2.7 & 37.0 & 55.5 & - & 5.8 \\
\hline+07 & LK46D & 18,000 & 4.2 & 6.5 & 4.1 & 32.7 & 45.7 & 6.8 & 3.4 \\
\hline+09 & LK46D & 14,400 & 9.7 & 1.3 & 3.8 & 31.3 & 47.7 & 6.3 & 3.7 \\
\hline+11 & LK46D & 8,300 & 9.3 & 0.5 & 4.7 & 51.9 & 30.4 & 3.3 & 2.6 \\
\hline $3 \mathrm{Gr}$ & LK46D & 3,700 & 4.9 & 0.0 & 5.6 & 50.3 & 37.1 & 2.1 & 3.9 \\
\hline Total & & 77,900 & 6.6 & 3.1 & 5.1 & 36.1 & 44.9 & 4.2 & 3.4 \\
\hline
\end{tabular}

Inclusions defined as recognisable minerals $>10 \mu \mathrm{m}$ in size. For general data, see Timmerman et al. (2017)

$E$ eclogitic inclusions, $P$ peridotitic inclusions, $U N$ unidentified silicate, $s g$., single, mult., multiple

${ }^{a}$ Including boart; if not otherwise reported all diamonds are of gem and near-gem quality

${ }^{b}$ Percentage of total amount of inclusions calculated by total number of inclusions over number of diamonds sulphide inclusions account for $4.2 \%$ of the inclusion-bearing diamonds. Overall, the eclogitic inclusions dominate the silicate population, similar to reports in Shirey et al. (2002). In contrast, Deines and Harris (2004) reported an estimated distribution of diamond inclusions from Letlhakane production of $29.4 \%$ eclogitic, $31.7 \%$ peridotitic, and $38.9 \%$ sulphide inclusions, but it remains unclear according to which sampling parameters the inclusion abundance counting was performed.

Of the 91 studied inclusion-bearing diamonds presented here, 3 are peridotitic (i.e., harzburgitic or lherzolitic), 6 are websteritic, 8 diamonds have only sulphides and 74 have an eclogitic paragenesis of which 44 contain combined eclogitic silicate and sulphide inclusions.

\section{Diamond characteristics}

All diamonds fall within the resorption spectrum from octahedra to dodecahedra (Online Resource 2: Table ESM_2.1). Four octahedra are twinned and 29 diamonds were broken or chipped. The majority $(n=64)$ were colourless, 17 were colourless to pale yellow and 10 showed uneven colouration with yellow to brown graining or irregular brown cores with colourless rims.

\section{Growth structure}

The complexity of the diamond growth histories is illustrated by the CL images (Fig. 1). Blue CL fluorescence colours are visible in $67 \%$ of the diamonds and are related to both the $\mathrm{N} 3$ centre $\left(\mathrm{V}_{1} \mathrm{~N}_{3}\right)$, as well as $\mathrm{B}$ and $\mathrm{A}$ emission caused by nitrogen impurities in diamond (Collins 1992; van Wyk 1982; Welbourn et al. 1996). In addition to blue fluorescence, $22 \%$ of the diamonds have growth zones with yellow-green CL (Fig. 1a) colours either related to singlesubstitutional nitrogen ( $\mathrm{N}^{0}$; Boyd et al. (1994)), H3 (NVN; Clark and Davey (1984)) or $\mathrm{NiN}$ centres $\left(\mathrm{V}_{2} \mathrm{NiN}^{+}\right.$and $\mathrm{V}_{2} \mathrm{NiN}$; Dischler (2012)). Another $28 \%$ of the diamonds have slip lines with green fluorescence (Fig. 1b,c) formed during plastic deformation in the mantle (Varma 1970). The dislocations seem to be associated with the non-luminescent Type IIa layers, which are more vulnerable to plastic deformation (Brookes et al. 2000; Yu et al. 2012).

The growth patterns range from a single well-defined growth zone (Fig. 1d) to samples with multiple (2 to $4+$ ) growth zones (e.g., Fig. 1b, e) that are recognised by sharp boundaries that may border genetically unrelated growth layers. In contrast, resorption boundaries (e.g., Fig. 1e) separating distinct growth events may be more difficult to distinguish, but can be recognised by truncation of growth layering often followed by limited non-luminescent (Type II) growth $(15-120 \mu \mathrm{m})$. Approximately, $75 \%$ of the diamonds show at least one (Fig. 1f) distinct resorption event and hence record a complex growth history (Fig. 1g). The remaining $25 \%$ of samples had either no internal resorption boundary or no clear growth pattern.

\section{Nitrogen systematics}

The $\mathrm{N}$ content of 246 representative whole stones ranges from 12 to 1153 at. ppm with 9 to $100 \% \mathrm{~B}$ aggregation (Online Resource 2: Table ESM_2.2). Less than 1\% of these diamonds are pure Type IaA, 56\% are Type IaAB (i.e. $10-90 \%$ B), $6 \%$ are Type IaB, while the remaining $37 \%$ have $<200$ at. ppm $\mathrm{N}$ and hence, no efforts were made to quantify corresponding time/temperature constraints based on the analysed $N$ aggregation state. The whole stone data are used for reference in plots of $[N]$ vs $\% \mathrm{~B}$. 

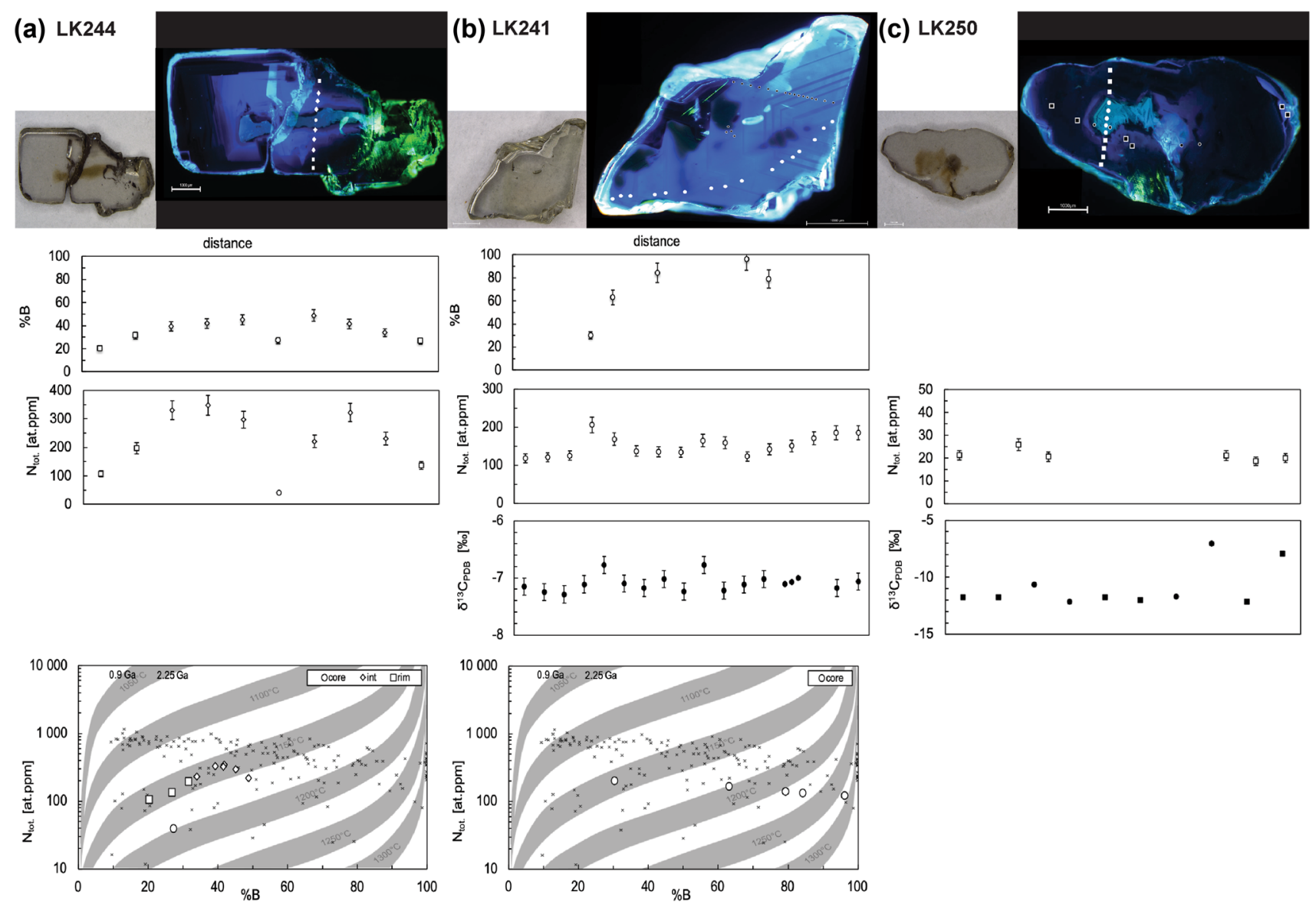

Fig. 1 Central plates of representative diamonds showing light microscope- \& CL-images, FTIR traverses (white marker) $\delta^{13} \mathrm{C}$ compositions of combustion samples (light grey marker) and of SIMS subdivided in traverses (black marker with stippled line) or measurements on polished fragments (black marker) together with their $\delta^{15} \mathrm{~N}$ data (dark grey) and derived [N]. a LK244 consists of two intergrown diamonds of which one has solid $\mathrm{CO}_{2}$ in its brown core; b LK241 shows oscillatory growth with a gradual shift in its composition; c LK250 is a low N-bearing diamond; $\mathbf{d}$ LK61 has high $\mathrm{N}$ in combination with very low aggregation and implies young diamond formation; e the successive growth layers in LK272 show a similar trend

FTIR traverses were determined on 62 representative Letlhakane plates and plotted together with their $\mathrm{C}-(\mathrm{N})$ isotope composition in Online Resource 3, with data provided in Online Resource 2. Of these plates, $20 \%$ show a constant C-N distribution close to analytical error $( \pm 10 \% \mathrm{~N}$ and $\pm 2 \% \mathrm{~B} ; \pm 1 \% \circ \delta^{13} \mathrm{C}$ ), whereas the majority have different $\mathrm{N}$ contents, aggregation and $\mathrm{C}$ isotope ratios in individual growth zones. Spot analyses $(n=1034)$ from traverses along the plates of all parageneses range from $\mathrm{N}$ below detection limit to 1944 at. ppm $\mathrm{N}$ and 0 to $100 \% \mathrm{~B}$ aggregation (Online Resource 2). Of these, data from the five known W-type diamonds are restricted to $\mathrm{N}$ contents between 6 and 286 at. ppm with a mean of $86 \pm 64$ at. ppm ( $n=65$ spot analyses). The largest $\mathrm{N}$ intra-diamond variation (1934 at. ppm) is to LK61, however slight changes in fluid composition between core, intermediate zone and rim are visible; f LK231 has a clear distinction between core and rim in its $\mathrm{C}-\mathrm{N}$ data, the core that formed at $0.75 \mathrm{Ga}$ was partially resorbed at a later stage potentially in combination with precipitation of the rim growth zone; g LK338 shows very complex growth patterns and different episodes of plastic deformation, dated inclusions were recovered from the core $(\sim 3 \mathrm{Ga})$, intermediate zone $(\sim 1 \mathrm{Ga})$ and rim $(\sim 0.3 \mathrm{Ga})$ zones, the light $\delta^{13} \mathrm{C}$ indicates the involvement of organic carbon in the diamond-forming fluid; $\mathbf{h}$ the core of LK47 formed at $\sim 2.3 \mathrm{Ga}$ whereas the intermediate and rim zones indicate formation at a later stage

recorded in eclogitic plate LK03, which ranges from below detection limit to 1934 at. ppm. The largest change in aggregation state is recorded in LK311, 95\%B. About $2 \%$ of the spot analyses traversing the plates are pure Type IaA, $48 \%$ are Type IaAB, $9 \%$ are Type IaB, $29 \%$ of the measurements have $<200$ at. ppm $\mathrm{N}$ and an additional $9 \%$ have $\mathrm{N}$ below detection limit.

Mantle residence temperatures $\left(T_{\mathrm{MR}}\right)$, calculated after Leahy and Taylor (1997), were modelled for all plates with sufficient $N$ (i.e. $>200$ at. ppm, $n=380$ spot analyses) based on diamond formation ages presented below corrected for the 93 Ma kimberlite eruption age. The calculated $T_{\mathrm{MR}}$ range from $1088{ }^{\circ} \mathrm{C}$ to $1373{ }^{\circ} \mathrm{C}$ assuming young diamond formation at kimberlite eruption, to $1021-1271{ }^{\circ} \mathrm{C}$ assuming 

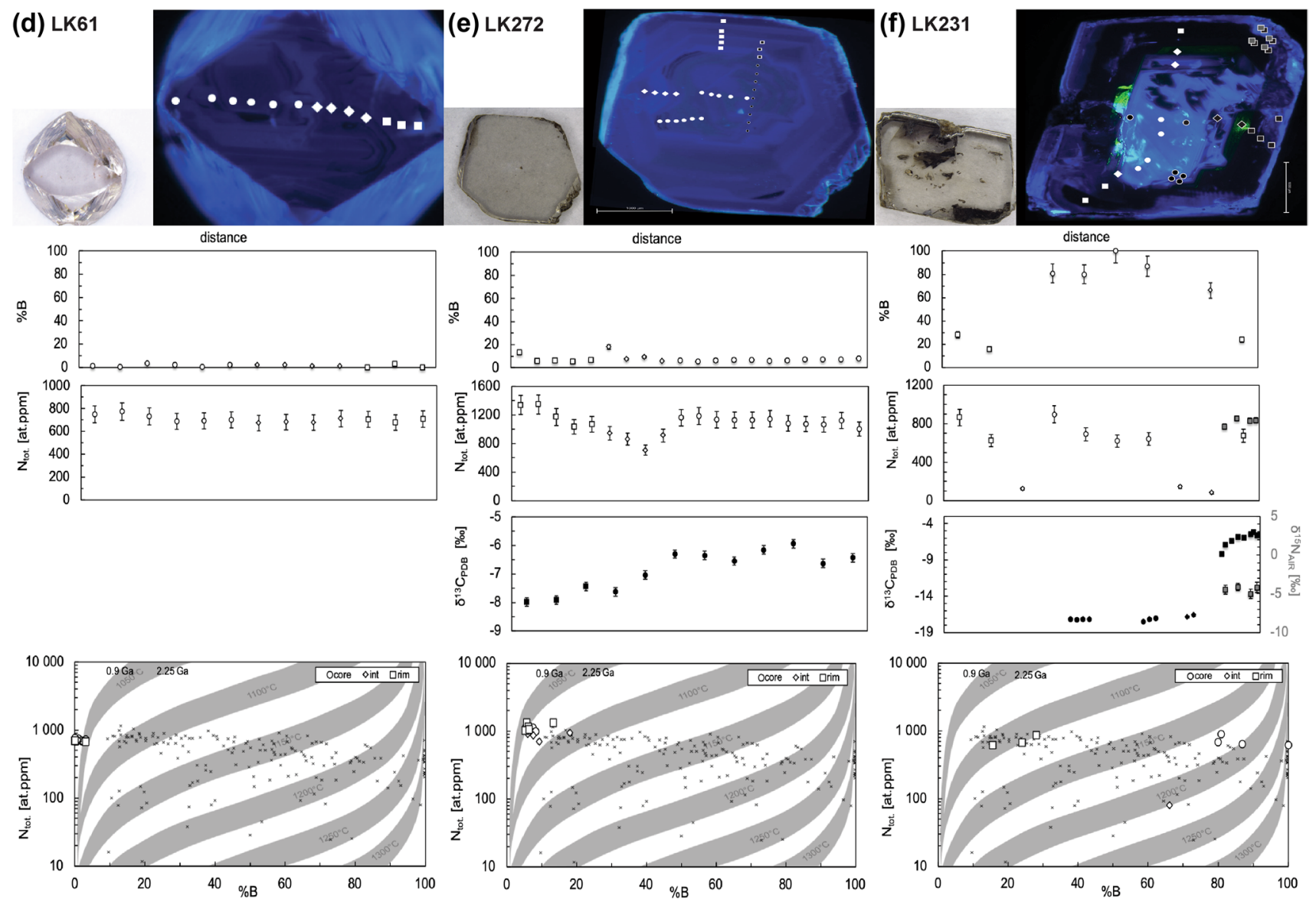

Fig. 1 (continued)

diamond formation at $2.3 \mathrm{Ga}$. Temperature differences between individual growth zones within a single diamond are generally $<50^{\circ} \mathrm{C}$ i.e., within the uncertainty (Kohn et al. 2016) but can exceed $150{ }^{\circ} \mathrm{C}$. For example, assuming diamond formation at $1 \mathrm{Ga}$ results in $T_{\mathrm{MR}}$ of $1044{ }^{\circ} \mathrm{C}$ in LK311 core and $1208{ }^{\circ} \mathrm{C}$ in its intermediate growth zone. These results illustrate the limits of one-stage thermal evolution models when applied to different growth zones within a diamond. Unfortunately, there are few diamonds with multiple dated inclusions from different growth zones that have sufficient $\mathrm{N}$ (>200 at. ppm) to model the time-temperature characteristics within a diamond (LK75, LK338; Fig. 1g).

\section{Nitrogen and carbon isotope systematics}

Nitrogen isotope ratios (Fig. 2a) from five diamonds (LK42, LK47, LK131, LK170, LK231; Fig. 1f,h) range from $-5.0 \%$ o to $+9.6 \%$ o $(n=16 ; \mathrm{SD} \pm 0.46 \%$ o to $\pm 1.73 \%$ o $)$ covering values typical for the mantle and recycled crustal/ sedimentary material (Cartigny et al. 2014). Core growth zones range from $+1.1 \%$ o to $+6.4 \%$ o $\left(\delta^{13} \mathrm{C}\right.$ of $-9.4 \%$ o to $-6.2 \%$ ), two measurements in intermediate zone of LK47
(Fig. 1h) have a $\delta^{15} \mathrm{~N}$ of $+9.5 \%$ o $\left(\delta^{13} \mathrm{C}\right.$ of $-16 \%$ to $-15 \%$ ), rim compositions range from $-4.5 \%$ o $\left(\delta^{13} \mathrm{C}\right.$ of $-6.9 \%$ to $-5.5 \%$ ) to $+8.9 \%$ o $\left(\delta^{13} \mathrm{C}\right.$ of $\sim-5.0 \%$ ) .

Carbon isotopes of individual growth zones from eclogitic Letlhakane diamonds range from $-38.5 \%$ o to $-1.7 \%$ o $(n=317)$ with a weak bi-modal distribution (Online Resource 1: Figure ESM_1.1) with modes at $-6.6 \%$ and - 16.2\%o. The lightest carbon isotope values (Fig. 2b) in the E-type diamonds are recorded only in core growth zones. Cores, however, have isotopic values that range from $-38.5 \%$ o to $-4.5 \%$ o, with $\mathrm{N}$ from below detection limit up to 771 at. ppm. Intermediate and rim zones are also variable with $\delta^{13} \mathrm{C}$ values, respectively, between $-24.9 \%$ o to $-1.7 \%$ o $(<963$ at. ppm N) and $-26.0 \%$ o to $-3.8 \%$ o $(<1346$ at. $\mathrm{ppm})$. The overall range is greater than reported previously for literature bulk analysis of eclogitic Letlhakane $(-18.3 \%$ o to $-3.6 \%$; mean $-6.7 \% \circ \pm 3.0 \%$; $n=35)$, Orapa ( $-28.6 \%$ o to $-2.1 \%$; mean $-12.5 \% \circ \pm 3.7 \%$; $n=17)$ or Damtshaa $(-17.6 \%$ o to $-4.4 \%$; mean $-6.6 \% \circ \pm 3.4 \%$; $n=18)$ diamonds (Chinn et al. 2018; Deines et al. 2009).

Data from the five websteritic Letlhakane diamonds in this study range from $-25.7 \%$ o to $-17.6 \%$ (Online Resource 1 : 

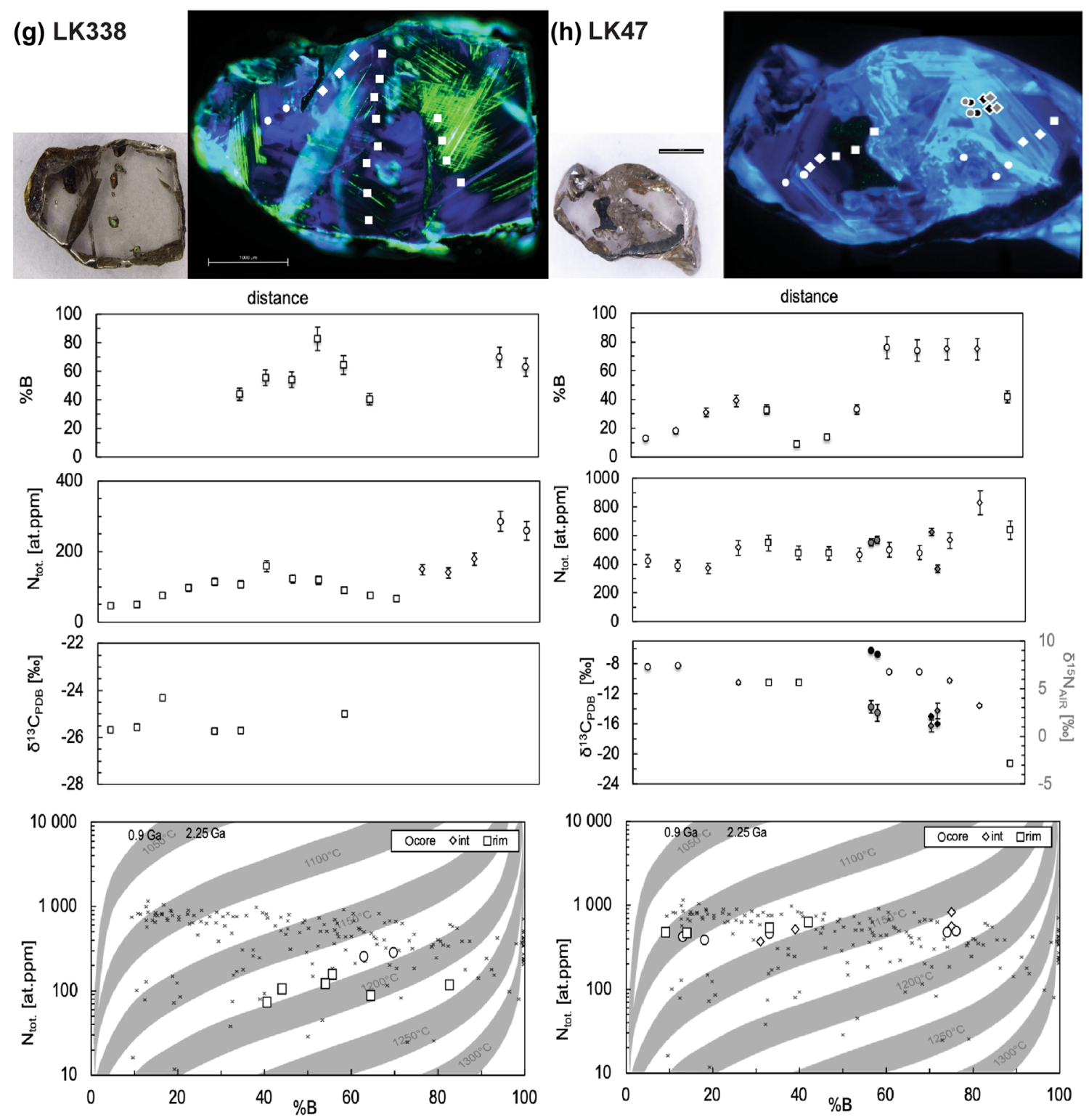

Fig. 1 (continued)

Figure ESM_1.1) with a mean of $-20.9 \%$ $\pm 2.7 \%$ ( $n=26)$. These data are similar to published websteritic means from Letlhakane $(-19.8 \% o, n=2)$ and Orapa $(-19.3 \% \circ \pm 2.3 \%$, $n=7)$ but different to Damtshaa $(-10.6 \%, n=1$; see Deines et al. (2009)).

Diamond growth: constant C-N A minority ( 20\%) of the studied diamond plates consist of a single or multiple growth zones that display oscillatory growth with a constant $\mathrm{N}$ distribution $( \pm 10 \%)$ and minor internal variation in $\delta^{13} \mathrm{C}\left( \pm 1 \%\right.$ ) e.g., LK48 with $\mathrm{N}<20$ at. ppm and $\delta^{13} \mathrm{C}$ of $-22.3 \pm 0.4 \%$; LK61 with $705 \pm 30$ at. ppm $\mathrm{N}$ and $1 \pm 1 \% \mathrm{~B}$ (Fig. 1d); LK70 with $593 \pm 48$ at. ppm N and $42 \pm 2 \% \mathrm{~B}$. Corresponding nitrogen $T_{\mathrm{MR}}$ assuming formation at $1 \mathrm{Ga}$, range from $1041-1070{ }^{\circ} \mathrm{C}$ (LK61) to $1140-1152{ }^{\circ} \mathrm{C}(\mathrm{LK} 70$, LK131). Robust age implications have only been obtained for diamond LK10 ( $\left.\mathrm{T}_{\mathrm{DM}}: 910 \mathrm{Ma}\right)$, that falls on a $998 \pm 140 \mathrm{Ma}$ isochron presented in Timmerman et al. (2017).

Diamond growth: variable C-N The majority of the studied diamonds $(\sim 80 \%)$ display internal variations in $\mathrm{N}$ content, $\mathrm{N}$ aggregation, $\delta^{13} \mathrm{C}$ (and $\delta^{15} \mathrm{~N}$ ) between growth zones. Several diamonds record abrupt changes between major growth zones (i.e., $\Delta \delta^{13} \mathrm{C}>4 \%$ ) associated with differences in CL-characteristics and FTIR data (Fig. 1f) e.g., LK01 with $\delta^{13} \mathrm{C}$ from $-14.3 \%$ (core) to $-5.6 \%$ (rim). The largest intra-diamond variation of $14.4 \%$ in $\delta^{13} \mathrm{C}$ is recorded in LK305 between core $(-22.0 \%)$ and 
Fig. 2 Covariation in $\mathrm{C}-\mathrm{N}$ data analysed on polished fragments of individual growth zones subdivided in core (circle), intermediate (diamond) and rim (square). Dark grey areas are based on black ' $x$ ' and represent literature data from Orapa (Deines et al., 1993; Cartigny et al., 1999; Chinn et al., 2018). a Covariation in $\delta^{13} \mathrm{C}$ and $\delta^{15} \mathrm{~N}$. Stippled lines represent hypothetical mixing curves between the mantle and isotopically distinct $\mathrm{C}-\mathrm{N}$ reservoirs with normal and biogenic carbonate after $\mathrm{Li}$ et al. (2019). b Covariation of $\delta^{13} \mathrm{C}$ and $\mathrm{N}$ content as atomic ppm of individual growth zones. The carbon data show a bi-modal distribution, also observed in literature data from Orapa. Data from the five websteritic Letlhakane diamonds in this study range from $-25.7 \%$ o to - 17.6\% (Online Resource 1: Figure ESM_1.1) with a mean of $-20.9 \%$ o $\pm 2.7 \%$ o $(n=26)$. These data are similar to published websteritic means from Letlhakane $(-19.8 \%, n=2)$ and Orapa $(-19.3 \% \circ \pm 2.3 \%$, $\mathrm{n}=7$ ) but different to Damtshaa $(-10.6 \%$ o, $n=1$; see Deines et al. (2009)).
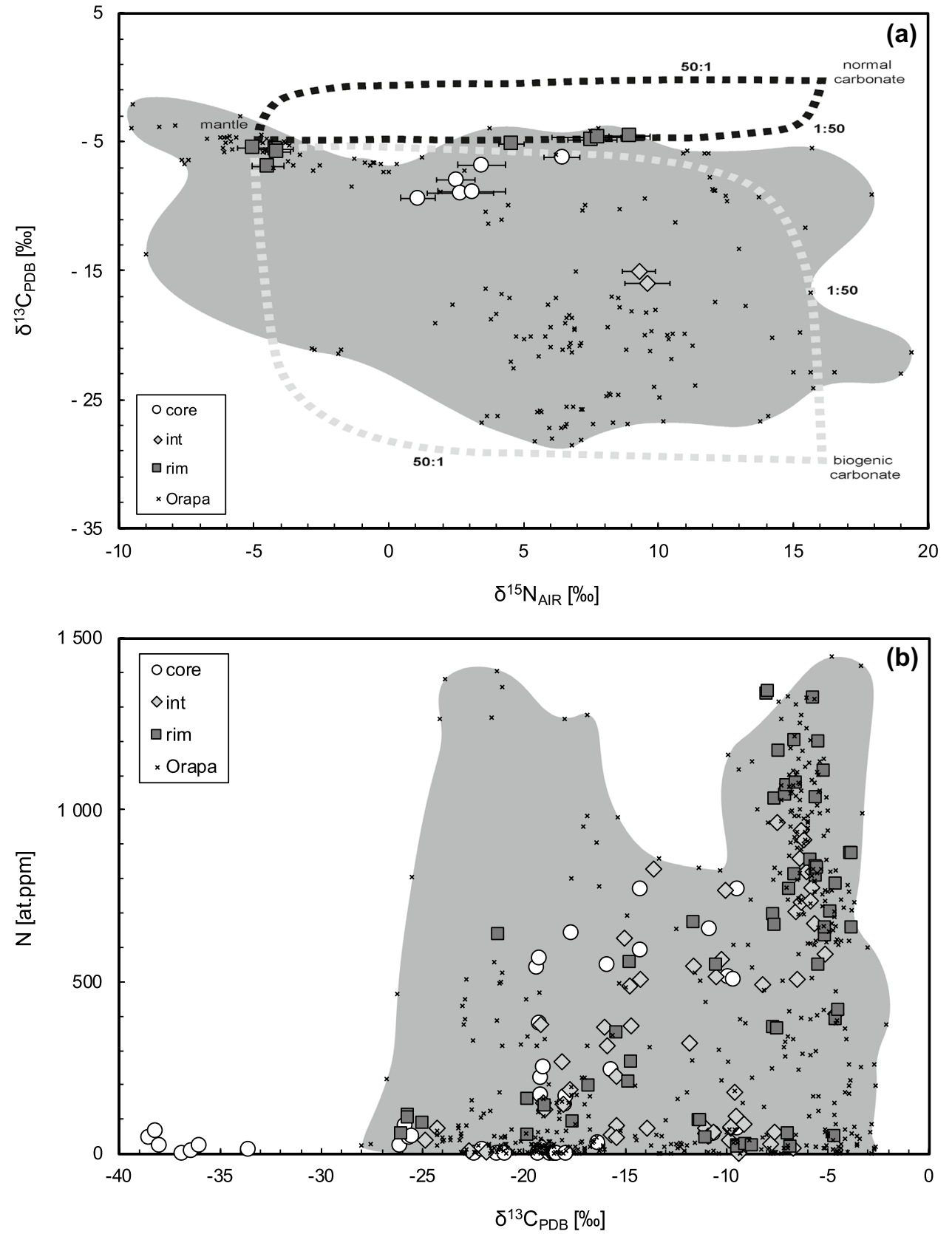

rim (- 7.5\%o), while LK60 and LK231 have differences of up to $12.8 \%$ and $12.2 \%$, respectively (Fig. 1f). The variation within individual major growth zones is normally less than $2 \%$ e.g., in LK18 ( $T_{\mathrm{MR}}$ : $\left.1088-1134{ }^{\circ} \mathrm{C}\right)$ with $\delta^{13} \mathrm{C}$ from -7.2 to $-5.1 \%$, in LK79 $\left(T_{\mathrm{MR}}: 1102-\right.$ $1128{ }^{\circ} \mathrm{C}$ ) with $\delta^{13} \mathrm{C}$ from -19.1 to $-17.8 \%$ and an inclusion age $>2.3 \mathrm{Ga}$ for the intermediate zone (Timmerman et al. 2017), in LK95 ( $\left.T_{\mathrm{MR}}: 1144-1156{ }^{\circ} \mathrm{C}\right)$ with $\delta^{13} \mathrm{C}$ from $-4.9 \%$ to $-4.5 \%$. Internal differences of $4.2 \%$ o were found in the core of LK362, of $2.7 \%$ and $4.4 \%$ in the intermediate zones of LK50 and LK60, respectively, and of $2.6 \%$ in the rim of LK231. These data potentially illustrate the difficulties in three-dimensional sampling of diamond fragments of a specific growth zone for GSMS analyses of $\mathrm{C}$ isotopes. A Rayleigh fractionation process (Cartigny et al. 2001; Deines 1980) could explain the variations observed within some major growth zones, but few diamonds (e.g., LK241, LK272; Fig. 1b, e) have detailed traverses to fully investigate this possibility.

\section{Inclusion geochemistry}

Sulphide, garnet (gnt), clinopyroxene (cpx), orthopyroxene (opx), kyanite, and coesite inclusions were identified in the studied diamonds. 


\section{Major element composition}

In total, 68 garnet inclusions in 21 diamonds from Letlhakane, 1 from Orapa and 2 from Damtshaa were analysed (Online Resource 2: Table ESM_2.4). The garnets have $\mathrm{Cr}_{2} \mathrm{O}_{3}$ contents of $0-17.5 \mathrm{wt} \%$ and magnesium numbers [Mg\#: molar $100 \mathrm{Mg} /(\mathrm{Mg}+\mathrm{Fe})]$ of 47-90, typical of peridotitic (5\%; P-type), eclogitic (83\%; E-type) and websteritic (12\%; W-type) parageneses (Fig. 3a). Eighteen clinopyroxenes in 9 diamonds with $\mathrm{Mg \#}$ of 73-94 and $\mathrm{Cr} \#$ [Cr\#: molar $100 \mathrm{Cr} /(\mathrm{Cr}+\mathrm{Al})]$ of 0-56 (Fig. 3b) are classified following the nomenclature of Morimoto et al. (1988), as diopsides (LK200) with Cr\#> 50 (P-type), omphacites (LK03, LK18, LK27, LK47, LK75, LK79, LK131) with low Cr\#<4 (E-type) and augites (LK40, LK286, LK338) with transitional Cr\# of 7-30 (W-type). Three orthopyroxene (opx) inclusions (LK129) have magnesium numbers of 73-79, $\mathrm{TiO}_{2}$ contents of $\sim 0.10 \mathrm{wt} \%$ and $\mathrm{Na}_{2} \mathrm{O}$ contents of $<0.04$ wt $\%$. Based on their Mg\#<86 (Stachel and Harris 2008), they are classified as websteritic.

Classification into compositional groups Based on differences in the $\mathrm{CaO}-\mathrm{Cr}_{2} \mathrm{O}_{3}$ diagram of Grütter et al. (2004) and other major element contents, the garnets can be subdivided into a minimum of six compositionally different chemical groups (Fig. 3c): (i) sub-calcic 'high' $\mathrm{Cr}_{2} \mathrm{O}_{3}$ P-type garnets in the harzburgitic G10 field (LK58, LK101), (ii) W-type 'high' $\mathrm{TiO}_{2}$ garnets from the G5 'high' Cr field (LK113), (iii) W-type 'low' $\mathrm{TiO}_{2}$ garnets from the $\mathrm{G} 5$ 'high' $\mathrm{Cr}$ field (LK338, LK346), iv) W-type 'low' $\mathrm{FeO}$ and $\mathrm{CaO}$, 'high' $\mathrm{TiO}_{2}$ and $\mathrm{Cr}_{2} \mathrm{O}_{3}$ garnets from the $\mathrm{G} 4$ field (LK40), v) E-type 'high' $\mathrm{FeO}$ and $\mathrm{CaO}$, 'low' $\mathrm{TiO}_{2}$ and $\mathrm{Cr}_{2} \mathrm{O}_{3}$ garnets from the G4 field (LK50, LK224, LK268, LK280), vi) the remaining E-type garnets from the G3 field have a large compositional range but do not clearly define distinct populations.

The clinopyroxenes can be subdivided into similar populations as the garnets: (i) P-type 'high' Cr\# (>50), 'high' Mg\# (>90) clinopyroxene (LK200), (iii) W-type 'high' Cr\# (>25), 'low' $\mathrm{TiO}_{2}$ clinopyroxenes (LK338), (iva) W-type 'high' Cr\# (5-12) in the transitional field from eclogitic to peridotitic clinopyroxenes in combination with low $\mathrm{Na}_{2} \mathrm{O}$ (<1.8 wt\%; LK40, LK286), ivb) E-type 'high' Cr\# (2-5) and $\mathrm{Na}_{2} \mathrm{O}$ (2.4-3.5 wt\%; LK79, LK131). The remaining E-type clinopyroxenes have extremely 'low' $\mathrm{Cr} \#$ but a range of other chemical compositions and define no clear sub-populations (vi).

\section{Trace element patterns}

The harzburgitic, eclogitic and websteritic garnets have C-1 chondrite-normalised trace element patterns (Online Resource 2: Table ESM_2.5) generally within the range previously reported in garnet inclusions in diamonds worldwide
(Stachel et al. 2004a). The harzburgitic garnets (Fig. 4a) have sinusoidal $R E_{N}$ patterns with $L_{R E E_{N}}$ increasing from La to a maximum at $\mathrm{Nd}$, decreasing $\mathrm{MREE}_{\mathrm{N}}$ and flat to increasing $\mathrm{HREE}_{\mathrm{N}}$. In contrast, some eclogitic garnets have a steep positive slope in the $\mathrm{LREE}_{\mathrm{N}}$ and fairly flat $\mathrm{MREE}_{\mathrm{N}}$ and $\mathrm{HREE}_{\mathrm{N}}$, while others have humped $\mathrm{REE}_{\mathrm{N}}$ patterns with a positive slope in the $\mathrm{LREE}_{\mathrm{N}}$ peaking at $\mathrm{Nd}$ and decreasing in the $\mathrm{MREE}_{\mathrm{N}}$ to flat or decreasing $\mathrm{HREE}_{\mathrm{N}}$ (Fig. 4b). Some garnets have Eu anomalies (Eu/Eu*: 0.25-1.7). Websteritic garnets (Fig. 4c) have flatter REE ${ }_{N}$ patterns than eclogitic garnets but also show a positive slope in $\mathrm{LREE}_{\mathrm{N}}$ with relatively flat $\mathrm{MREE}_{\mathrm{N}}$ and $\mathrm{HREE}_{\mathrm{N}}$ and negative Eu anomalies (Eu/Eu*: 0.34-0.88).

The dated eclogitic and websteritic clinopyroxenes typically show trace element patterns (Online Resource 2: Table ESM_2.5) with a positive slope in the LREE peaking at $\mathrm{Nd}$ and decreasing in the MREE-HREE (Fig. 4d). The slopes from the peak at $\mathrm{Nd}$ to Lu are steeper in the eclogitic (13-15 times chondrite) and websteritic (27-77 times chondrite) clinopyroxenes in this study than worldwide sources $(\mathrm{Nd} /$ $\mathrm{Lu}$ of \pm 5 ) reported in Stachel et al. (2004a). This may be caused by the different analytical techniques, as this study did not analyse bulk inclusions by laser ablation, but matrix residua corrected to reference materials for $>90 \%$ loss of $\mathrm{Nd}$ and Sm during column chemistry. Additionally, the overall abundance of REE in cpx inclusions is lower compared to garnets and in cases of small inclusion size $(<5 \mu \mathrm{g})$, a strong decrease from MREE to HREE in chondrite-normalised patterns is seen in the garnets resulting in elevated $(\mathrm{Ce} / \mathrm{Yb})_{\mathrm{N}}$ ratios. Overall, inclusions recovered from the same growth zone of a diamond (e.g., LK338 cpx C, D, E) have comparable $\mathrm{REE}_{\mathrm{N}}$ patterns and Eu anomalies (Fig. 4). Validity of the trace element compositions was demonstrated in Gress et al. (2021) that confirmed a general agreement between such matrix residua collected from chromatography columns and bulk analysis of inclusions.

Parental fluid compositions Fluid compositions in equilibrium with the silicate inclusions were calculated from partition coefficients for supercritical liquids at $1000{ }^{\circ} \mathrm{C}$ and 4 $\mathrm{GPa}$ (Kessel et al. 2005). The metasomatic nature of diamond formation involves volatile-rich liquids which are commonly referred as high-density $\mathrm{C}-\mathrm{H}-\mathrm{O}$ fluids or low degree melts at supra-solidus conditions (see Shirey et al. (2019)). Henceforth, the term fluid is used in context with diamondforming processes, because distinction between the role of high-density fluids and melts is difficult to resolve. Overall, the calculated fluids (Fig. 5) show a wide range of LREE enrichment $\left(\mathrm{La}_{\mathrm{N}}=12-7013,(\mathrm{La} / \mathrm{Gd})_{\mathrm{N}}=2-993\right.$ and $(\mathrm{Ce} /$ $\left.\mathrm{Yb})_{\mathrm{N}}=20-19174\right)$ comparable to the range of compositions recorded in kimberlites (Mitchell 1986) and high-density fluids trapped in fibrous diamonds from other locations in Southern Africa (Schrauder et al. 1996; Weiss et al. 2013). 
Fig. 3 (right) a Peridotitic, eclogitic and websteritic garnet inclusions in diamonds from the Orapa kimberlite cluster classified by molar $\mathrm{Mg \#}$ versus $\mathrm{Cr}_{2} \mathrm{O}_{3}$ contents with compositional fields from Deines et al. (1993). b Classification scheme of Grütter et al. (2004) with distinction between individual compositional garnet groups i to vi. c Composition of clinopyroxene inclusions in Letlhakane diamonds by molar Mg\# versus $\mathrm{Cr} \#$ for individual compositional groups according to garnets. Literature data (empty markers) from Deines and Harris (2004), Deines et al. (1993), Deines et al. (2009), Stachel et al. (2004b), and Timmerman et al. (2017) \& (2018)
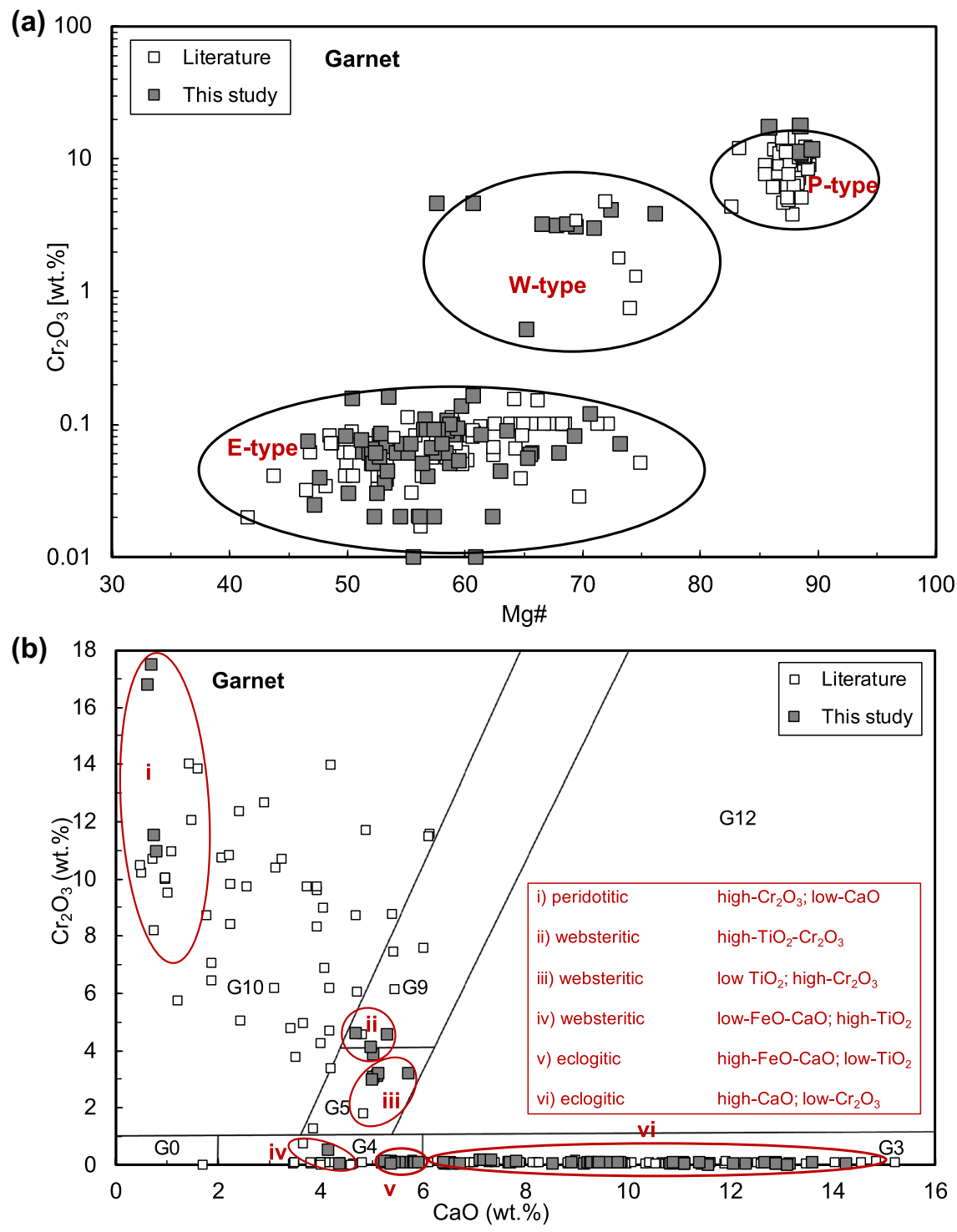

(c)

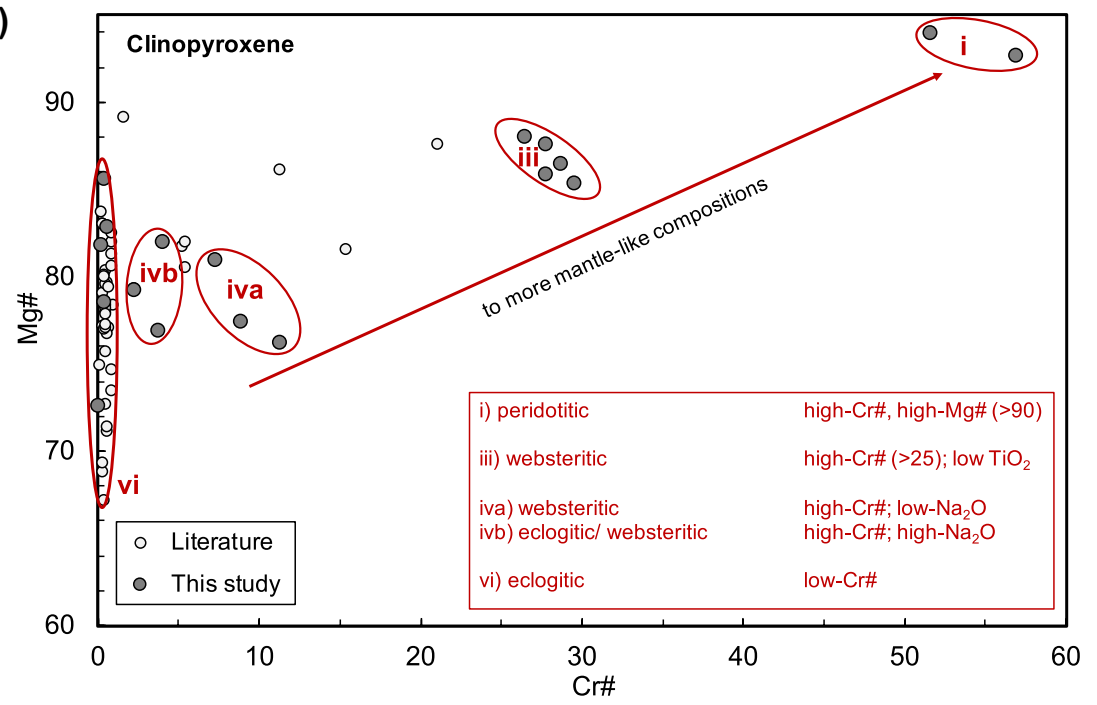



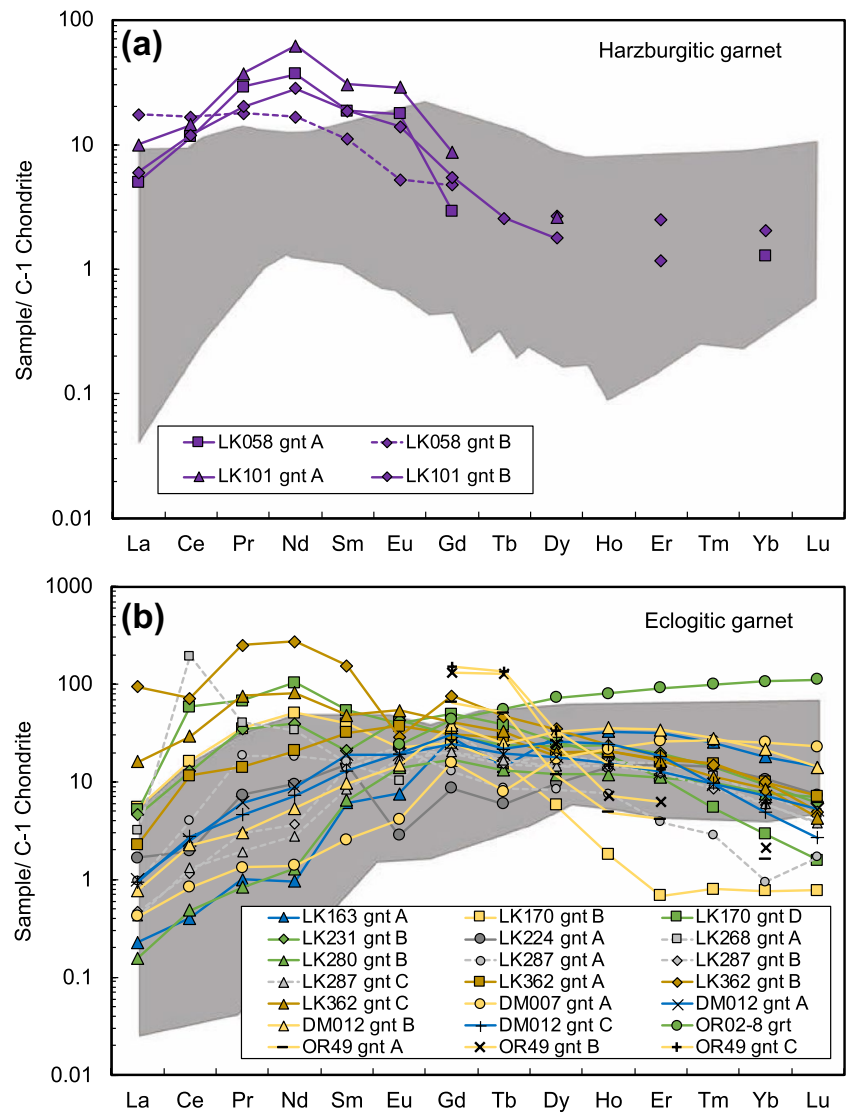

Fig. 4 Chondrite-normalised REE patterns of a harzburgitic, $\mathbf{b}$ eclogitic, c websteritic garnets, and $\mathbf{d}$ eclogitic and websteritic cpx from Letlhakane. Colours correspond to different Sm-Nd ages (see Fig. 5);
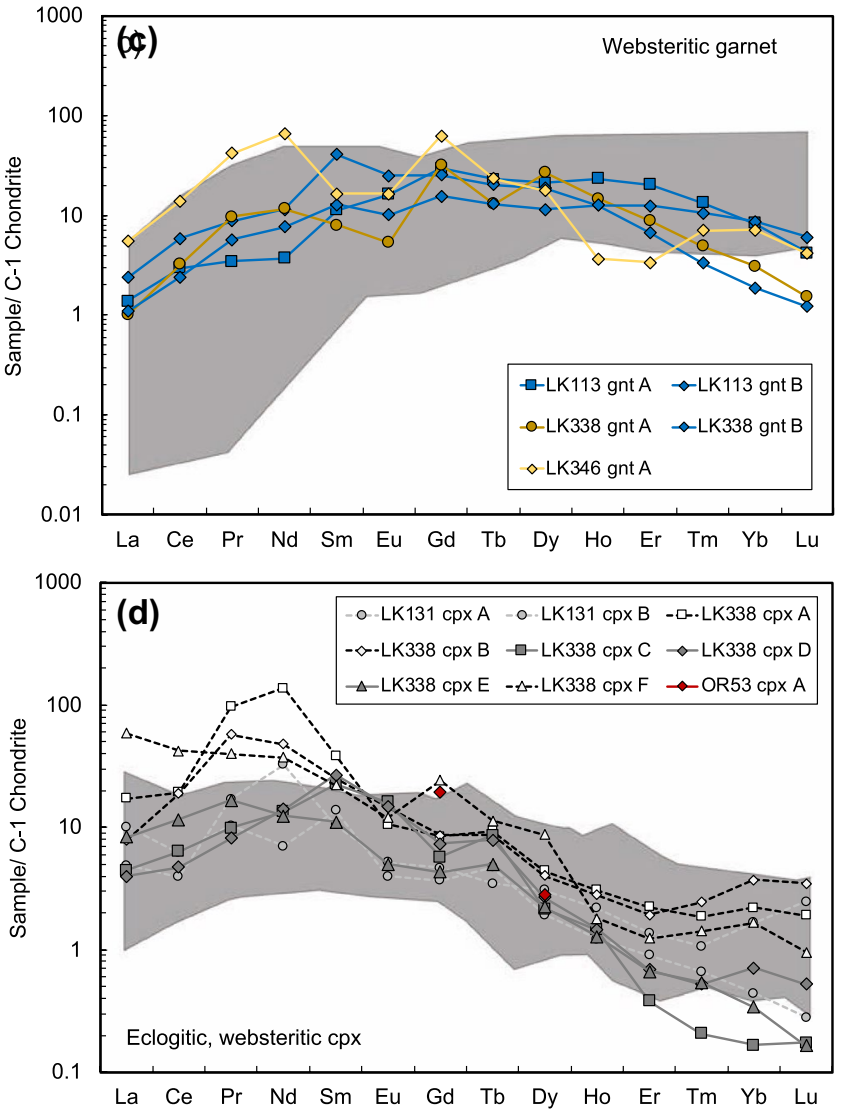

stippled lines are inclusions that were not dated and had no chromatography; grey shaded area represents literature data for harzburgitic or eclogitic inclusions from worldwide sources (Stachel et al. 2004a)
Fig. 5 Theoretical $\mathrm{REE}_{\mathrm{N}}$ patterns of parental diamondforming fluids derived from clinopyroxene and garnet inclusions using partitioning coefficients at $4 \mathrm{GPa} / 1000^{\circ} \mathrm{C}$ from Kessel et al. (2005). The fluids show a wide compositional range comparable to high-density fluids trapped in fibrous diamonds from other southern African mines (Weiss et al. 2013); worldwide average kimberlite composition from Schrauder et al. (1996)

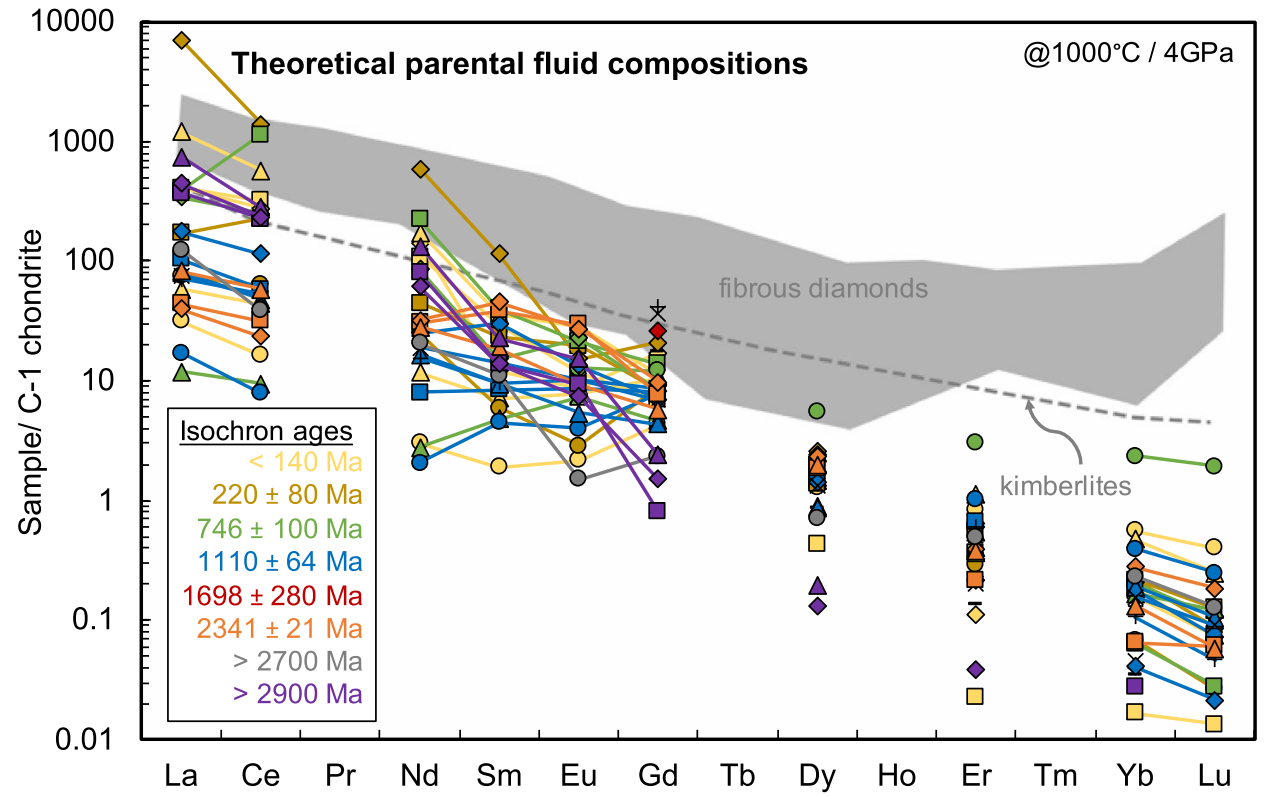


The inferred fluid compositions for individually dated inclusions recovered from the same growth zone are reproducible with $(\mathrm{La} / \mathrm{Gd})_{\mathrm{N}}$ for example in E-type DM012 (8-11), P-type LK101 (295-313) and W-type LK113 (13-25).

\section{Sm-Nd isotope systematics}

$\mathrm{Sm}$ and $\mathrm{Nd}$ concentrations in the garnet inclusions vary from 0.16 to $6.48 \mathrm{ppm} \mathrm{Sm}$ and $0.24-10.37 \mathrm{ppm}$ Nd (Table 2). The ${ }^{143} \mathrm{Nd} /{ }^{144} \mathrm{Nd}$ ratios of garnets vary from 0.5099 to 0.5175 with ${ }^{147} \mathrm{Sm} /{ }^{144} \mathrm{Nd}$ between 0.05 and 1.2 and $\varepsilon \mathrm{Nd}_{i}$ (corrected for kimberlite eruption at $93 \mathrm{Ma}$ ) between -50.6 and + 94.6. Rubidium and Sr (Online Resource 2: Table ESM_2.6) range to both lower and higher concentrations than previously reported (0.04-4.61 ppm Rb, 2.05-25.1 ppm Sr). Half of the garnets have low ${ }^{87} \mathrm{Rb} /{ }^{86} \mathrm{Sr}$ ratios $(<0.09)$, which in combination with their large range in ${ }^{87} \mathrm{Sr} /{ }^{86} \mathrm{Sr}$ ratios (0.7049-0.7165) indicate a multi-stage history and incorporation of radiogenic strontium (Timmerman et al. 2017). The remaining garnets have higher $\mathrm{Rb} / \mathrm{Sr}$ ratios $(0.1-0.7)$ and may provide age constraints. For some garnets, however, the overall $\mathrm{Rb}$ and $\mathrm{Sr}$ contents are low resulting in large uncertainties for the isotope ratios (Online Resource 2: Table ESM_2.6). In addition, blank contribution to Rb and $\mathrm{Sr}$ can represent up to $51 \%$, resulting in an overall limited significance for the $\mathrm{Rb}-\mathrm{Sr}$ isotope data.

The cpx inclusions have 1.1-9.9 ppm Nd, 0.25-2.19 ppm $\mathrm{Sm}$ and ${ }^{143} \mathrm{Nd} /{ }^{144} \mathrm{Nd}$ of $0.5116-0.5120$ with ${ }^{147} \mathrm{Sm} /{ }^{144} \mathrm{Nd}$ of $0.12-0.14$ (Table 2). Initial $\varepsilon \mathrm{Nd}_{i}$ range between -18.1 and - 10.6. Sr (189-277 ppm) and Rb (0.13-3.0 ppm) contents are associated with low ${ }^{87} \mathrm{Rb} /{ }^{86} \mathrm{Sr}$ ratios $(<0.04)$ in combination with moderate ${ }^{87} \mathrm{Sr} /{ }^{86} \mathrm{Sr}$ ratios (0.7063-0.7067; Online Resource 2: Table ESM_2.6).

Sm-Nd isotope age arrays The broad compositional range of garnet and cpx inclusions define five well- (Group 1-5) and three less well-constrained (Group $a-c$ ) arrays in a Sm$\mathrm{Nd}$ isochron diagram (Fig. 6). Published data from Letlhakane are included and combined with the new data from the Orapa and Damtshaa mines. From old to young we distinguish: (Group a) three sub-calcic garnets with $\mathrm{T}_{\mathrm{CHUR}}$ model ages $\geq 2.9$ Ga (2.87-3.38 Ga); (Group b) although with a significant blank contribution $(\sim 30 \%)$, one eclogitic garnet has a $\mathrm{T}_{\text {CHUR }}$ model age $>2.7 \mathrm{Ga}$; (Group 1) five cpx and one garnet define a $2341 \pm 21 \mathrm{Ma}$ age array with an $\varepsilon \mathrm{Nd}_{i}$ of + 5.9; (Group 2) four cpx describe a $1698 \pm 280$ Ma age array with $\varepsilon \mathrm{Nd}_{i}$ of +3.3 ; (Group 3) eleven garnets define a $1100 \pm 64 \mathrm{Ma}$ age with negative $\varepsilon \mathrm{Nd}_{i}$ of -1.7 ; (Group 4) four garnets plot along a $746 \pm 100 \mathrm{Ma}$ array with $\varepsilon \mathrm{Nd}_{i}$ of -2.7 ; and (Group 5) seven garnets and three cpx define a line with a slope equivalent to an age of $220 \pm 80 \mathrm{Ma}$ with $\varepsilon \mathrm{Nd}_{i}$ of 1.3 ; (Group c) eight garnets with unradiogenic ${ }^{143} \mathrm{Nd} /{ }^{144} \mathrm{Nd}\left(\varepsilon \mathrm{Nd}_{i}\right.$ from -42.5 to -2.2$)$ plot below a $140 \mathrm{Ma}$ reference line and are outside the uncertainty of Group 5. Notably, inclusions on the age arrays (Group 1-5) are of both eclogitic and websteritic paragenesis suggesting diamond formation occurs contemporaneously in both eclogitic and websteritic protoliths.

\section{Discussion}

The recognition of multiple growth zones and traces of plastic deformation within the diamonds (Fig. 1a, c, f, g) is in line with their isotopic heterogeneity and the marked compositional range of the inclusions. Together, diamonds and inclusions provide incontrovertible evidence for diamond formation in a variety of distinct eclogitic/websteritic/harzburgitic/lherzolitic environments in the SCLM beneath the Orapa kimberlite cluster at different times. Similar observations were made elsewhere at various mines [see compilation in Stachel and Harris (2008)].

\section{Sm-Nd isotope constraints on diamond formation ages}

Garnet within a harzburgitic assemblage contains the vast majority of the REE (>90\%) and hence, the model ages of sub-calcic garnets have direct age significance. Initially, we will review the peridotitic inclusions in an attempt to constrain the formation age of the oldest diamond populations. Inclusions from eclogitic assemblages, the majority of inclusions in this study and in Timmerman et al. (2017), will be considered thereafter, before examining inclusions of websteritic paragenesis from Letlhakane and subsequently eclogitic inclusions from Orapa and Damtshaa.

Defining which inclusions are co-genetic is a key aspect of the approach. Most growth zones surrounding analysed inclusions have low nitrogen and thus, the nitrogen systematics cannot be used as a main discriminator for determining which groups of minerals are co-genetic and hence potentially form isochron relationships. Since depleted mantle model ages $\left(\mathrm{T}_{\mathrm{DM}}\right)$ yield unrealistically old ages due to intersection of the depleted mantle model curve with CHUR at $\sim 2.9 \mathrm{Ga}, \mathrm{Nd}$ isotope $\mathrm{T}_{\mathrm{CHUR}}$ model ages are reported. Overall, the model ages are only considered indicative for E-/W-type diamonds due to the evidence of recycled crustal material in many studied eclogitic diamond populations (Deines et al. 1984; Smart et al. 2011; Taylor et al. 1990) and due to variable trace element partitioning into clinopyroxene and garnet. Such partitioning depends on the presence of accessory phases and, for example, the $\mathrm{CaO}$ contents of garnets fractionating the $\mathrm{Sm} / \mathrm{Nd}$ ratios in the mineralfluid system (Aulbach and Jacob 2016; Barth et al. 2001; Harte and Kirkley 1997; O'Reilly and Griffin 1995). This complicates interpretation of the time-integrated $\mathrm{Sm}-\mathrm{Nd}$ 


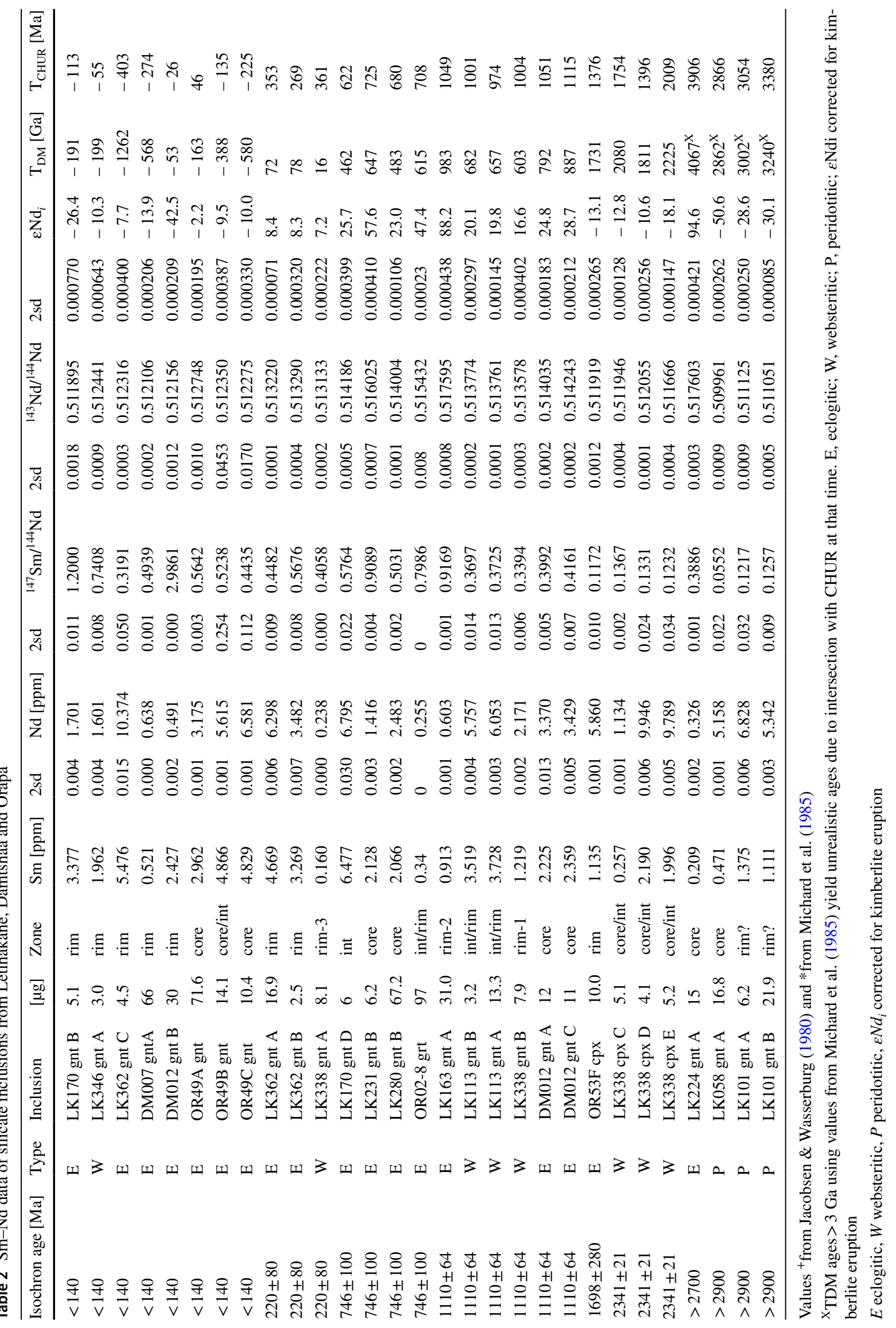


Fig. $6 \mathrm{Sm}-\mathrm{Nd}$ isochron compilation of individual harzburgitic, eclogitic and websteritic garnet (square) and clinopyroxene (circle) inclusions from Letlhakane, Orapa (stippled markers) and Damtshaa (dotted markers) in this study and literature data for Letlhakane and Orapa (white diamonds) from Timmerman et al. (2017). Note: $\varepsilon \mathrm{Nd}_{i}$ of the isochron in reference to CHUR; individual colours represent cogenetic inclusions

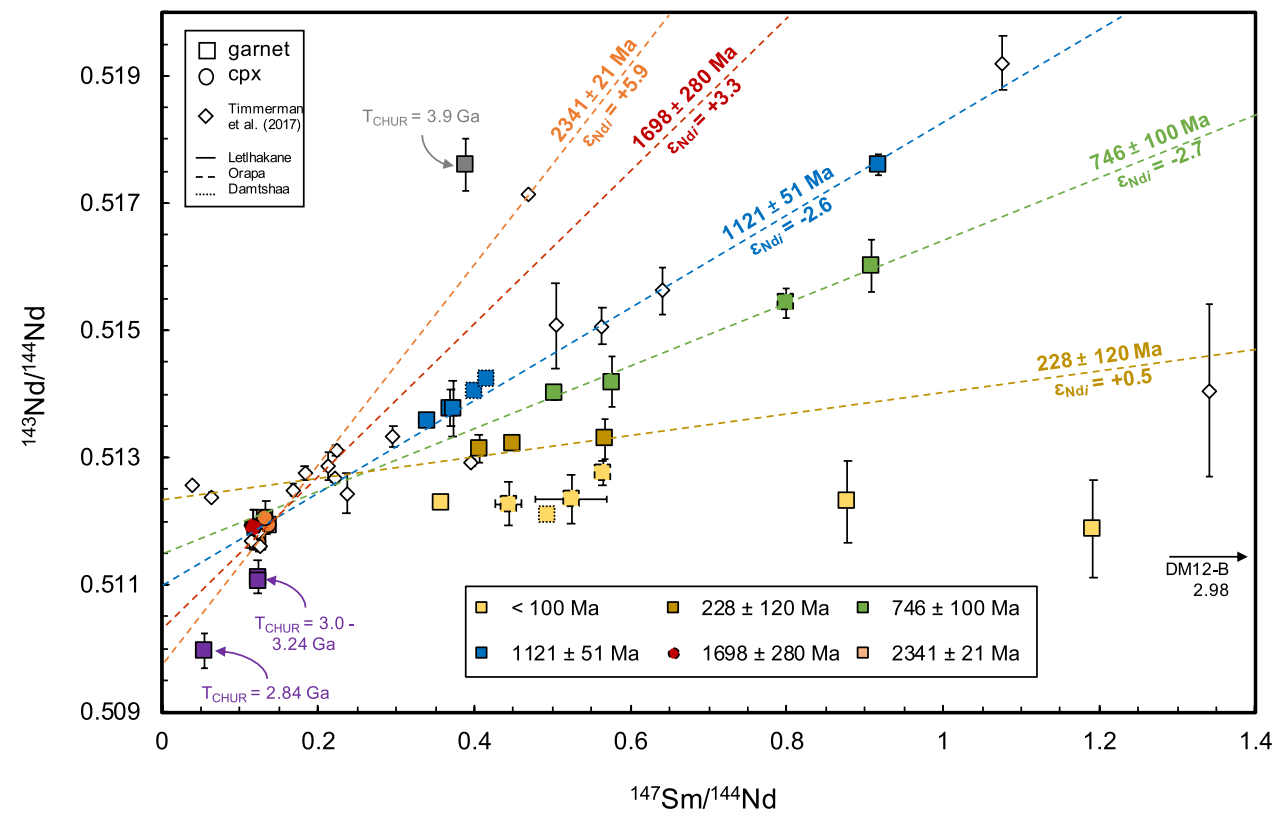

isotope systematics. Therefore, co-genetic relationships were established in a similar way to Timmerman et al. (2017) and Koornneef et al. (2017) i.e., inclusions were divided into groups with comparable $\mathrm{T}_{\mathrm{CHUR}}$ ages of $<0.4 \mathrm{Ga},<0.75 \mathrm{G}$ $\mathrm{a},<1.15 \mathrm{Ga},<2.7 \mathrm{Ga}$ and $>2.7 \mathrm{Ga}$ and further subdivided based on mineral composition, ${ }^{87} \mathrm{Sr} /{ }^{86} \mathrm{Sr}$ and the calculated enrichment of LREE relative to MREE using $(\mathrm{La} / \mathrm{Gd})_{\mathrm{N}}$ of the parental fluids (Fig. 7).

\section{Peridotitic diamonds at Letlhakane}

The $\mathrm{T}_{\mathrm{CHUR}}$ model ages $(\geq 2.9 \mathrm{Ga})$ of the three harzburgitic garnets (Group $a$ ) provide the first age constraints for harzburgitic diamond formation at Letlhakane (and the entire Orapa cluster). Diamond formation apparently resulted in metasomatic re-enrichment of an originally highly meltdepleted protolith. The garnets of LK058 (0.7077) and LK101 (0.7136) have different ${ }^{87} \mathrm{Sr} /{ }^{86} \mathrm{Sr}$ ratios (Online Resource 2: Table ESM_2.6), Ca/Cr ratios (0.04-0.07) and do not define a precise $\mathrm{Sm}-\mathrm{Nd}$ isochron $(2360 \pm 580 \mathrm{Ma})$. The low initial ratio $\left(\varepsilon \mathrm{Nd}_{i}-8.7\right)$ implies an older formation age, consistent with older $\mathrm{T}_{\mathrm{CHUR}}$ model ages. Similar Mesoarchean model ages of 3.2-3.3 Ga were reported for harzburgitic diamonds from Finsch and Kimberley (Richardson et al. 1984) along with a $2.95 \pm 0.07 \mathrm{Ga} \mathrm{Sm}-\mathrm{Nd}$ isochron from Venetia (Koornneef et al. 2017) and Lu-Hf, Sm-Nd and $\mathrm{Re}-\mathrm{Os}$ peridotite xenolith data in the Kalahari Craton (Branchetti et al. 2021; Carlson et al. 1999; Simon et al. 2007).

The variable but high $\mathrm{Cr}_{2} \mathrm{O}_{3}$ contents (12-17 wt $\%$ ) of the LK peridotitic inclusions suggest different degrees of original source depletion and/or varying pressure in diamond formation (Deines et al. 2009; Griffin et al. 1999; Stiefenhofer et al. 1997). Application of the $\mathrm{Cr} / \mathrm{Ca}$-in-garnet barometer of Grütter et al. (2006) using a $40 \mathrm{~mW} / \mathrm{m}^{2}$ geotherm yields 5.9-6.1 GPa ( $200 \mathrm{~km}$ depth) for LK058 gnt A, B and 7.8-8.0 GPa for the high-Cr LK101 gnt A, B $(\sim 260 \mathrm{~km}$ depth). There are potentially increased uncertainties from microprobe measurements when using unpolished surfaces of the inclusions; however, these pressure estimates are comparable to those recorded in a harzburgitic garnet from the nearby Karowe mine (7 GPa; Motsamai et al. (2018)). Deep formation/storage near the base of the lithosphere is supported by the inferred $T_{\mathrm{MR}}$ of $1195^{\circ} \mathrm{C}$ in LK058 (66 at. ppm $\mathrm{N}$ with $71 \% \mathrm{~B}$ ) that overlaps with equilibration temperatures calculated from olivine-garnet diamond inclusion thermometry from Orapa $\left(1230 \pm 80^{\circ} \mathrm{C}\right.$; Stachel et al. (2004b)), Karowe $\left(1200{ }^{\circ} \mathrm{C}, 5.2 \mathrm{GPa}\right.$; Motsamai et al. (2018)) and the inferred geophysical structure of the SCLM beneath Letlhakane (Griffin et al. 2003; Shirey et al. 2002).

The LK inclusions overlap with the radiogenic ${ }^{87} \mathrm{Sr} /{ }^{86} \mathrm{Sr}$ ratios of garnet harzburgite xenoliths (0.7091) and the Sm-Nd model age $\left(T_{\mathrm{CHUR}}: \sim 3.2 \mathrm{Ga}\right)$ that were interpreted to demonstrate the ancient origin of the lithospheric root beneath Letlhakane (Stiefenhofer et al. 1997). The trace element contents of the harzburgitic garnet inclusions (Online Resource 2: Table ESM_2.5; Fig. 4a) indicate metasomatic enrichment of a depleted protolith, as the garnets have low Zr (24-48 ppm) and Y contents (1.8-3.5 ppm). They are characterised by high LREE and low HREE $\left((\mathrm{La} / \mathrm{Gd})_{\mathrm{N}}\right.$ 295-467) as has been observed in garnet inclusions from Orapa and Karowe (Motsamai et al. 2018; Stachel et al. 2004b). Overall, harzburgitic diamonds ( $86 \%$ of peridotitic diamonds) are widespread in the SCLM (Stachel and Harris 


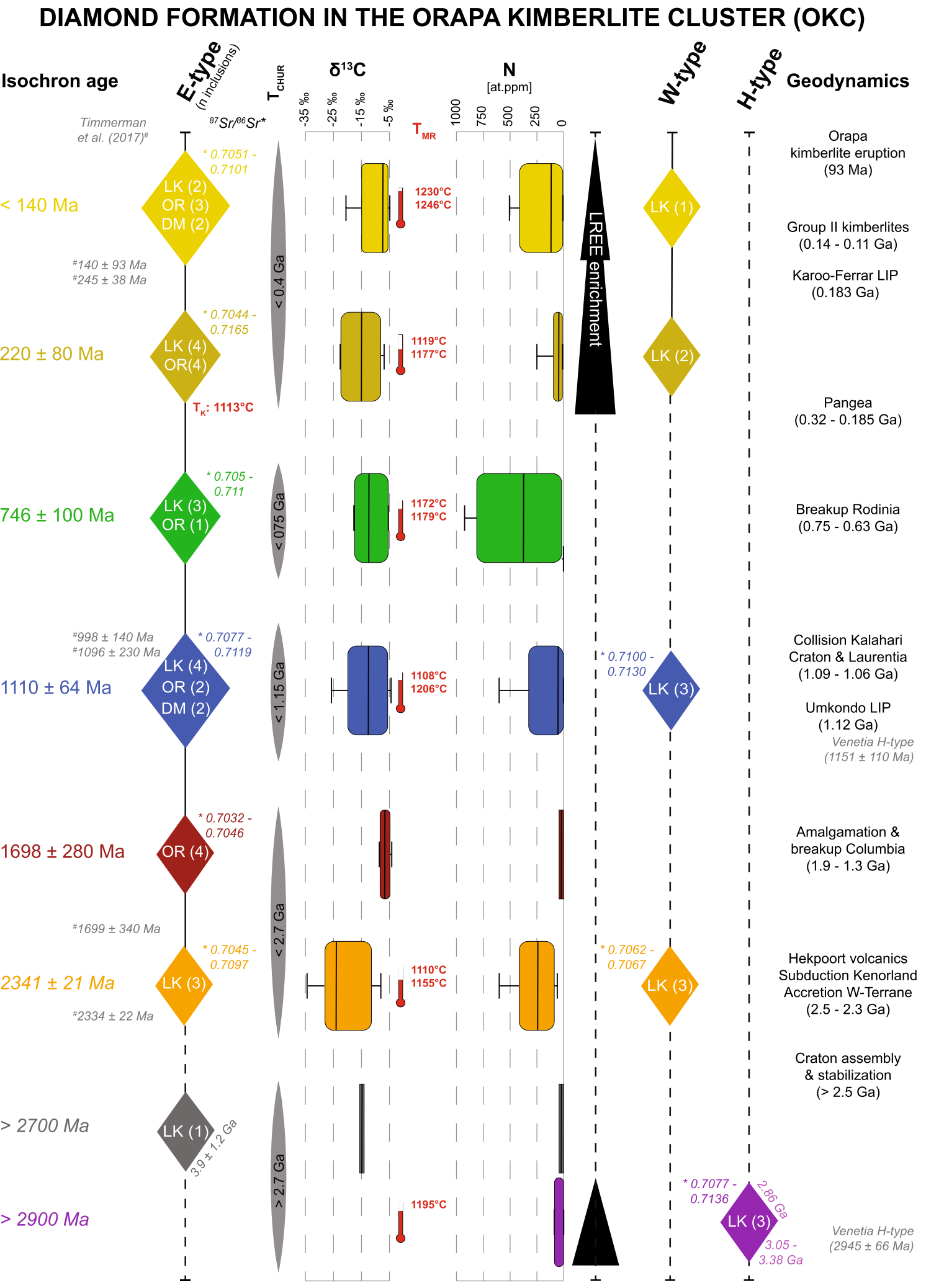

Fig. 7 The evolution of eclogitic (E-type), websteritic (W-type) and harzburgitic (H-type) diamonds from the Orapa kimberlite cluster in context with the geodynamic setting (see Sect. 4.4.1) in southern Africa. Isochron ages (coloured font) refer to diamond formation in Letlhakane (LK), Orapa (OR) and Damtshaa (DM) with the number of dated inclusions $(n)$ in brackets. Isochron ages from Orapa and
Letlhakane (grey font) are from Timmerman et al. (2017), from Venetia (grey font) from Koornneef et al (2017). Box and whisker plots for carbon isotopes and nitrogen content together with general properties of ${ }^{87} \mathrm{Sr} /{ }^{86} \mathrm{Sr}$ composition, $T_{\mathrm{CHUR}}$ model ages, mineral equilibration temperature $\left(T_{\mathrm{K}}\right)$ and integrated mantle residence time $\left(T_{\mathrm{MR}}\right)$ relate to the corresponding age population. Note: the figure is not to scale 
2008) but appear rare in Botswana. Two small $(<2 \mu \mathrm{g})$ lherzolitic cpx were recovered from the core of LK200 that has relatively low $\mathrm{N}$ content ( $\sim 50$ at. $\mathrm{ppm})$. The $\mathrm{N}$ aggregation is above $80 \%$ but no firmer age constraints can be made.

\section{Simultaneous and episodic formation of eclogitic and websteritic diamonds}

The eclogitic inclusion data from this study help refine the eclogitic diamond formation ages previously reported from Letlhakane by Timmerman et al. (2017): $245 \pm 38 \mathrm{Ma}(292 \pm 140 \mathrm{Ma}$; this study), $998 \pm 140 \mathrm{Ma}$ (now $1029 \pm 97 \mathrm{Ma}$ ) and at Orapa for $1699 \pm 340 \mathrm{Ma}$ (now

Table $3 \mathrm{Sm}-\mathrm{Nd}$ ages of inclusions from Letlhakane (LK), Orapa (OR) and Damtshaa (DM)

\begin{tabular}{|c|c|c|c|c|c|c|c|c|}
\hline \multirow{2}{*}{$\begin{array}{l}\text { Age } \\
\text { group }\end{array}$} & \multirow{2}{*}{$\begin{array}{l}\text { Isochron } \\
\text { age [Ma] }\end{array}$} & \multirow[t]{2}{*}{${ }^{143} \mathrm{Nd} /{ }^{144} \mathrm{Nd}_{i}$} & \multirow[t]{2}{*}{$2 \mathrm{sd}$} & \multirow[t]{2}{*}{ MSWD } & \multirow[t]{2}{*}{$\overline{\varepsilon N d_{i}}$} & \multirow[t]{2}{*}{ Type } & \multicolumn{2}{|r|}{ Inclusions } \\
\hline & & & & & & & This study & Timmerman et al. (2017) \\
\hline (a) & $>2900$ & & & & & $P$ & $\begin{array}{l}\text { LK058 gnt A; LK101 gnt A, } \\
\text { B }\end{array}$ & \\
\hline \multirow[t]{3}{*}{ (b) } & $>2700$ & & & & & E & LK224 gnt A & LK79-2 cpx \\
\hline & $2334 \pm 22$ & 0.50993 & 0.00006 & 0.0048 & 6.2 & $E$ & - & LK33-2 grt; LK47-3 cpx; LK75-1 \\
\hline & $3309 \pm 2100$ & 0.50898 & 0.00180 & 1.8 & 12.8 & W & LK338 cpx C, D, E & - \\
\hline \multirow[t]{2}{*}{ (1) } & $2341 \pm 21$ & 0.50991 & 0.00005 & 1.5 & 5.9 & $E+W$ & LK338 cpx C, D, E & LK33-2 grt; LK47-3 cpx; LK75-1 \\
\hline & $1699 \pm 340$ & 0.51061 & 0.00044 & 1.09 & 3.3 & E & - & $\begin{array}{l}\text { OR06-7 cpx; OR07-1 cpx; OR09-1 } \\
\mathrm{cpx}\end{array}$ \\
\hline \multirow[t]{7}{*}{ (2) } & $1698 \pm 280$ & 0.51061 & 0.00036 & 0.54 & 3.3 & E & OR53 F cpx & $\begin{array}{l}\text { OR06-7 cpx; OR07-1 cpx; OR09-1 } \\
\text { cpx }\end{array}$ \\
\hline & $998 \pm 120$ & 0.51139 & 0.00039 & 0.029 & 0.9 & $E$ & - & LK09-2 grt; LK10-2 grt; LK50 grt \\
\hline & $1096 \pm 230$ & 0.51140 & 0.00014 & 0.0 & 3.5 & $E$ & - & OR02-7 grt; OR20-1 grt \\
\hline & $1879 \pm 2500$ & 0.50910 & 0.0066 & 0.0 & -21.7 & $E$ & DM012 gnt $A, C$ & - \\
\hline & $1029 \pm 97$ & 0.51132 & 0.00031 & 0.18 & 0.2 & $E$ & LK163 gnt $A$ & LK09-2 grt; LK10-2 grt; LK50 grt \\
\hline & $825 \pm 1900$ & 0.51170 & 0.00470 & 0.029 & 2.9 & W & $\begin{array}{l}\text { LK113 gnt A, B; LK338 gnt } \\
\text { B }\end{array}$ & - \\
\hline & $1038 \pm 94$ & 0.51126 & 0.00026 & 0.19 & -0.6 & $E+W$ & $\begin{array}{l}\text { LK163 gnt A; LK113 gnt A, } \\
\text { B; LK338 gnt B }\end{array}$ & LK09-2 grt; LK10-2 grt; LK50 grt \\
\hline \multirow[t]{2}{*}{ (3) } & $1100 \pm 64$ & 0.51113 & 0.00018 & 0.64 & -1.7 & $E+W$ & $\begin{array}{l}\text { LK163 gnt A; LK113 gnt A, } \\
\text { B; LK338 gnt B; DM012 gnt } \\
\text { A,C }\end{array}$ & $\begin{array}{l}\text { LK09-2 grt; LK10-2 grt; LK50 grt; } \\
\text { OR02-7 grt; OR20-1 grt }\end{array}$ \\
\hline & $751 \pm 150$ & 0.51152 & 0.00052 & 0.78 & -2.9 & $E$ & $\begin{array}{l}\text { LK170 gnt D; LK231 gnt B; } \\
\text { LK280 gnt B }\end{array}$ & - \\
\hline \multirow[t]{6}{*}{ (4) } & $746 \pm 100$ & 0.51153 & 0.00040 & 0.39 & -2.7 & $E$ & $\begin{array}{l}\text { LK170 gnt D; LK231 gnt B; } \\
\text { LK280 gnt B; OR02 gnt } 8\end{array}$ & - \\
\hline & $140 \pm 93$ & 0.51254 & $6.2 \mathrm{E}-05$ & 2.4 & 1.6 & $E$ & - & $\begin{array}{c}\text { OR02-6 grt; OR07-2 grt; OR08-2 } \\
\text { cpx; OR18-4 cpx }\end{array}$ \\
\hline & $245 \pm 38$ & 0.512291 & 0.00007 & 0.89 & -0.6 & $E+W$ & - & LK40-1 cpx; LK42 grt; LK75-2 grt \\
\hline & $293 \pm 250$ & 0.51223 & 0.00059 & 10.7 & -0.5 & $E$ & LK362 gnt $A, B$ & LK42 grt; LK75-2 grt \\
\hline & $385 \pm 190$ & 0.51211 & 0.00029 & 0 & -0.6 & W & LK338 gnt A & LK40-1 cpx \\
\hline & $294 \pm 110$ & 0.51224 & 0.00023 & 5.7 & -0.4 & $E+W$ & $\begin{array}{l}\text { LK338 gnt A; LK362 gnt A, } \\
\text { B }\end{array}$ & LK40-1 cpx; LK42 grt; LK75-2 grt \\
\hline (5) & $220 \pm 80$ & 0.51242 & 0.00015 & 8.7 & 1.3 & $E+W$ & $\begin{array}{l}\text { LK338 gnt A; LK362 gnt A, } \\
\text { B }\end{array}$ & $\begin{array}{l}\text { LK40-1 cpx; LK42 grt; LK75-2 grt; } \\
\text { OR02-6 grt; OR07-2 grt; OR08-2 } \\
\text { cpx; OR18-4 cpx }\end{array}$ \\
\hline (c) & $<140$ & & & & & $E+W$ & $\begin{array}{l}\text { LK170 gnt B; LK346 gnt A; } \\
\text { LK362 gnt C; DM007 gnt A; } \\
\text { DM012 gnt B; OR049 gnt A- } \\
\text { C }\end{array}$ & \\
\hline
\end{tabular}


$1698 \pm 280 \mathrm{Ma})$. An additional age of $751 \pm 150 \mathrm{Ma}$ was found for eclogitic garnet inclusions at Letlhakane. No new eclogitic inclusions were found associated with the reported $2322 \pm 22 \mathrm{Ma}$ age (Fig. 6). Initial ratios of all the isochron ages are close to CHUR with $\varepsilon \mathrm{Nd}_{i}$ ranging from -2.9 to 3.3 (Table 3). Additionally, two less well-constrained eclogitic events (Groups b and $c$ ) are indicated with notable un-/ radiogenic ${ }^{143} \mathrm{Nd} /{ }^{144} \mathrm{Nd}$. Combining eclogitic ages with data of websteritic inclusions from Letlhakane (and subsequently with eclogitic inclusions from Orapa and Damtshaa) suggests simultaneous and episodic diamond formation in both diamond parageneses. Hence, the following section will critically assess the diamond and inclusion properties of the different petrogenetic diamond suites to evaluate a genetic relationship and constrain the scale and nature of diamondforming processes (also see Online Resource 1.3: Tectonomagmatic implications).

\section{Archaean eclogitic diamond formation Older than $2.7 \mathrm{Ga}$ (Group b)}

The Sm-Nd isotope systematics of the eclogitic garnet LK224 are extreme but the age poorly constrained $\left(T_{\text {CHUR }}=3.9 \pm 1.2 \mathrm{Ga}\right)$. The inclusion has supra-chondritic REE contents with LREE depletion, flat MREE/HREE and a negative Eu anomaly $\left(\mathrm{Eu} / \mathrm{Eu}^{*}=0.25\right.$, Fig. $\left.4 b\right)$. The existence of Archaean eclogitic diamonds $(>2.5 \mathrm{Ga})$ has previously been indicated in the Kaapvaal Craton (Pearson and Harris 2004; Richardson et al. 2001, 2004; Shirey et al. 2008; Westerlund et al. 2004). The diamond is low in $\mathrm{N}(<20$ at. ppm) and does not allow firmer constraints on its age. The moderately light $\delta^{13} \mathrm{C}(-9.2 \%)$ in combination with the negative Eu anomaly suggests the involvement of recycled crustal component(s) in the source of the metasomatic fluid or eclogitic protolith (Aulbach and Jacob 2016).

\section{Paleoproterozoic diamond-forming events At $2341 \pm 21 \mathrm{Ma}$ (Group 1)}

Websteritic LK338 records a complex growth history (Fig. 1g) and its inclusions were recovered from distinct growth zones. Three cpx from its core have $\mathrm{T}_{\mathrm{CHUR}}$ ages between 1.4 and $2.0 \mathrm{Ga}$ with moderately radiogenic ${ }^{87} \mathrm{Sr} /{ }^{86} \mathrm{Sr}$ (0.706). In combination with the $2.3 \mathrm{Ga}$ eclogitic inclusions (0.7045 and 0.7097) of Timmerman et al. (2017) that have similar $\mathrm{Sm} / \mathrm{Nd}$ ratios ( 0.2 and 0.3 ), these data imply diamond formation at $2341 \pm 21 \mathrm{Ma}$ with an $\varepsilon \mathrm{Nd}_{i}$ of +5.9 (Table 3). The websteritic LK338 core has light $\delta^{13} \mathrm{C}$ $(-25.6 \%)$ as do the eclogitic inclusions $\left(\delta^{13} \mathrm{C}-33.6 \%\right.$ to $-9.2 \% o$ ) and suggest the involvement of subducted and recycled (Archaean) organic material (Cartigny et al. 1999; Timmerman et al. 2017). This conclusion is re-enforced by heavy $\delta^{15} \mathrm{~N}$ in the cores (Fig. 2a) of LK42 $(+2.3 \% \circ \pm 0.9 \%$ ) and LK47 $(\sim+9.3 \% \circ)$. Because no LREE data are available for these eclogitic inclusions, only the MREE and HREE of the inferred diamond-forming metasomatic fluid compositions can be compared. Calculated $(\mathrm{Dy} / \mathrm{Yb})_{\mathrm{N}}$ ratios for the eclogitic (5-9) and websteritic (8-29) inclusions overlap and potentially suggest simultaneous interaction of a fluid or series of fluids of similar composition with eclogitic and websteritic portions of the SCLM. The similar $T_{\mathrm{MR}}$ of websteritic LK338 (core: 259 at. ppm N, $63 \% \mathrm{~B} ; T_{\mathrm{MR}}: 1155^{\circ} \mathrm{C}$ ) and these eclogitic diamonds (1119-1165 $\left.{ }^{\circ} \mathrm{C}\right)$ imply comparable storage conditions and thus, suggest that the Eand W-type diamonds precipitated at a similar level in the SCLM.

At $1698 \pm 280$ Ma in Orapa (Group 2)

Four eclogitic Orapa cpx with unradiogenic ${ }^{87} \mathrm{Sr} /{ }^{86} \mathrm{Sr}$ (0.7032-0.7046) define an Sm-Nd age of $1698 \pm 280 \mathrm{Ma}$ and indicate the involvement of isotopically depleted source material with $\varepsilon \mathrm{Nd}_{i}$ of +3.3 (Table 3 ). The diamonds are low in $\mathrm{N}\left(<20\right.$ at. ppm) and have mantle-like $\delta^{13} \mathrm{C}(-7.5 \%$ o to $-5.6 \%$ ). Only cpx inclusions define this event in comparison to the predominance of garnet inclusions that define the other events, but notably, the cpx have comparable $\mathrm{T}_{\text {CHUR }}$ model ages $(\sim 2 \mathrm{Ga})$. As yet, there is no evidence for this event at Letlhakane or Damtshaa, suggesting localised diamond formation. This finding could, however, represent sampling bias towards diamonds carrying multiple, large silicate and sulphide inclusions.

\section{Mesoproterozoic diamond formation At $1100 \pm 64 \mathrm{Ma}$ (Group 3)}

Websteritic garnets from the intermediate zones of LK338 and LK113 have 5 wt\% CaO, moderate $\mathrm{Mg \#}(68-72)$ and radiogenic ${ }^{87} \mathrm{Sr} /{ }^{86} \mathrm{Sr}(0.710-0.713)$. The inclusions have comparable $\mathrm{Sm}-\mathrm{Nd}$ isotope systematics and define an isochron with a large uncertainty (Table 3 ). $\mathrm{T}_{\mathrm{CHUR}}$ model ages are between 974 and $1208 \mathrm{Ma}$ (Table 2). Four eclogitic LK garnets that are more calcic (5.7-12.3 wt\% $\mathrm{CaO}$ ) with lower $\mathrm{Mg} \#$ (50-72), have overlapping radiogenic ${ }^{87} \mathrm{Sr} /{ }^{86} \mathrm{Sr}(0.7078-0.7120)$ and define an $\mathrm{Sm}-\mathrm{Nd}$ age of $1029 \pm 97 \mathrm{Ma}$ with an $\varepsilon \mathrm{Nd}_{i}$ of +0.2 . Similar LREE enriched characteristics of the inferred diamond-forming fluid (Fig. 5) in the eclogitic $\left((\mathrm{La} / \mathrm{Gd})_{\mathrm{N}} 2-25\right)$ and websteritic $\left((\mathrm{La} / \mathrm{Gd})_{\mathrm{N}} 2-19\right)$ parageneses suggest the interaction of similar fluids with distinct protoliths. The combined data define an age of $1038 \pm 94 \mathrm{Ma}\left(\varepsilon \mathrm{Nd}_{i}-0.6\right)$. Two eclogitic garnets from Orapa (3.5-5.7 wt $\% \mathrm{CaO}, \mathrm{Mg} \#$ $\left.61-70,{ }^{87} \mathrm{Sr} /{ }^{86} \mathrm{Sr} 0.7081-0.7084\right)$ and Damtshaa (10.7 wt $\%$ $\left.\mathrm{CaO}, \mathrm{Mg} \# 47-51,{ }^{87} \mathrm{Sr} /{ }^{86} \mathrm{Sr} 0.7077\right)$ have inferred fluid characteristics with comparable LREE enrichment ((La/ Gd $)_{N}$ 8-11) and indicate diamond-forming events at $1096 \pm 230$ Ma beneath Orapa (Timmerman et al. 2017) and $1879 \pm 2500$ Ma beneath Damtshaa.

Combining data from the entire Orapa kimberlite cluster constrains the time that eclogitic and websteritic diamonds 
formed to $1100 \pm 64 \mathrm{Ma}(n=11)$ with $\varepsilon \mathrm{Nd}_{i}-1.7$. Notably, the age does not change significantly when different parageneses are combined but the uncertainty improves. The near Bulk Earth initial ratio of the isochron suggests the presence of recycled crustal material in the source of the diamond-forming fluids, which is supported by the light $\delta^{13} \mathrm{C}$ signatures observed in the eclogitic $(-20.5 \%$ o to $-7.0 \%$ o $)$ and websteritic $(-25.0 \%$ o to $-19.8 \%$ ) diamonds (Online Resource 2: Table ESM_2.4) and variable Eu anomalies (Eu/ $\mathrm{Eu}^{*}=0.7-0.9$ ). The integrated residence temperatures of corresponding N-bearing diamond growth zones are comparable $\left(T_{\mathrm{MR}}=1109-1206^{\circ} \mathrm{C}\right)$ and indicate similar conditions for subsequent storage in the SCLM. These consistent temperatures suggest that subsequent diamond-forming events that clearly affected some samples (e.g., LK338) have not significantly increased the average $T_{\mathrm{MR}}$, implying formation of the rims of these diamonds was not associated with major regional heating events.

\section{Neoproterozoic diamond formation At $746 \pm 100 \quad \mathrm{Ma}$ (Group 4)}

An eclogitic garnet from Orapa $(6.1 \mathrm{wt} \% \mathrm{CaO}, \mathrm{Mg} \#$ $65)$ and three eclogitic garnets (7.7-11.1 wt\% $\mathrm{CaO}, \mathrm{Mg} \#$ $\left.52-64,{ }^{87} \mathrm{Sr} /{ }^{86} \mathrm{Sr} 0.7049-0.7116\right)$ from Letlhakane define a $746 \pm 100$ Ma diamond-forming event with $\varepsilon \mathrm{Nd}_{i}-2.7$ (Table 3). Compositional variations in $\delta^{13} \mathrm{C}$ (LK170 intermediate: - 5.6\%o; LK231: - 17.3\%o; LK280: - 9.4\%o; OR02-8: $-6.8 \%$ ) and $\mathrm{N}$ content (670-900 at. ppm with $70-80 \% \mathrm{~B} ;<20$ at. ppm for LK280 and OR08-2) are within the typical range for eclogitic inclusions. Inferred metasomatic fluid compositions (Fig. 5) are also similar ((La/ $\left.\mathrm{Gd})_{\mathrm{N}} 3-42\right)$ and the integrated residence temperatures $\left(T_{\mathrm{MR}}=1172-1179{ }^{\circ} \mathrm{C}\right)$ indicate that these diamonds were stored under similar conditions.

\section{Phanerozoic diamond-forming events At 220 $2080 \mathrm{Ma}$ (Group 5)}

Eclogitic garnets from Letlhakane (LK42 rim, LK75 rim, LK362 rim) define an age of $293 \pm 250 \mathrm{Ma}$ but show an extended range in $(\mathrm{La} / \mathrm{Gd})_{\mathrm{N}}$ fluid ratios $(20-336)$ and light $\delta^{13} \mathrm{C}(-21.3 \%$ o to $-14.3 \%$ ) . Including the websteritic garnet LK338 $\left((\mathrm{La} / \mathrm{Gd})_{\mathrm{N}} 9 ; \delta^{13} \mathrm{C}-25.7 \% 0\right)$ and cpx LK40-1 $\left(\delta^{13} \mathrm{C}-20.5 \%\right.$ o recovered from rims of the diamonds, improves the isochron uncertainty to $294 \pm 110 \mathrm{Ma}$ with $\varepsilon \mathrm{Nd}_{i}+5.7$. Notably, diamond LK338 is a rare example providing evidence for episodic websteritic diamond growth, potentially spanning $>2 \mathrm{Gyr}$ with inclusions lying on the $2.34 \mathrm{Ga}, 1.10 \mathrm{Ga}$ and $0.22 \mathrm{Ga}$ isochrons. Such protracted diamond growth has only been established in a few diamonds (Pearson et al. 1999; Timmerman et al. 2017; Wiggers de Vries et al. 2013). The websteritic mineral equilibration temperature, $T_{\mathrm{K}}$ (Krogh 1988), from LK40 rim $(N<200$ at. ppm) yields a diamond formation temperature of $T_{\mathrm{K}}=1113{ }^{\circ} \mathrm{C}$ that overlaps with integrated mantle residence temperatures of $1119^{\circ} \mathrm{C}$ to $1165^{\circ} \mathrm{C}$ from the eclogitic diamonds $(N>200$ at. ppm) suggesting that diamond formation was not associated with a major thermal pulse and subsequent cooling.

Two eclogitic garnets (3.8-6.4 wt\% $\mathrm{CaO}, \mathrm{Mg} \#$ 62-65, $\left.{ }^{87} \mathrm{Sr} /{ }^{86} \mathrm{Sr} 0.7076-0.7080\right)$ and two cpx $(0.7044-0.7054)$ from Orapa yield an age that is within error of the Letlhakane diamonds, $140 \pm 93 \mathrm{Ma}$ with $\varepsilon \mathrm{Nd}_{i}+1.6$ (Timmerman et al. 2017). These host diamonds are low in $\mathrm{N}(<100$ at. ppm) and have heavier $\delta^{13} \mathrm{C}(-10.4 \%$ o to $-6.8 \%$ ). Combination of these inclusion data improves the precision of the diamond-forming event to $220 \pm 80 \mathrm{Ma}(\mathrm{n}=10)$ with $\varepsilon \mathrm{Nd}_{i}+1.3$ (Table 3).

\section{Younger than 140 Ma (Group c)}

Two eclogitic garnets from Letlhakane (LK170) have unradiogenic ${ }^{143} \mathrm{Nd} /{ }^{144} \mathrm{Nd}(0.5119-0.5123)$ and ${ }^{147} \mathrm{Sm} /{ }^{144} \mathrm{Nd}$ above 1 (Fig. 6). They have negative $\mathrm{T}_{\mathrm{CHUR}}$ ages and are outside the uncertainty of the $220 \pm 80 \mathrm{Ma}$ isochron implying extremely recent formation $(<140 \mathrm{Ma})$. A websteritic inclusion (LK346) has similar characteristics and the fluids inferred to have formed these inclusions are highly enriched in LREE $\left((\mathrm{La} / \mathrm{Gd})_{\mathrm{N}} 24-108\right)$. Further evidence for very recent diamond formation is given by three garnets from Orapa $\left({ }^{87} \mathrm{Sr} /{ }^{86} \mathrm{Sr} 0.7054-0.7081\right)$ and two from Damtshaa $\left({ }^{87} \mathrm{Sr} /{ }^{86} \mathrm{Sr}\right.$ 0.7055-0.7101). One of these samples (DM012 B) has an extreme ${ }^{147} \mathrm{Sm} /{ }^{144} \mathrm{Nd}$ of 2.98 . The negative $\varepsilon \mathrm{Nd}_{i}$ ( -42.5 to -2.2 ) of the inclusions (Table 2) indicates diamond formation involved a protolith and/or metasomatic fluids with time-integrated LREE enrichment such as Archaean to Proterozoic eclogites or orangeites/lamproites $\left(\varepsilon \mathrm{Nd}_{i}-28\right.$ to 0; see Fraser et al. (1985); Pearson et al. (2019)). These data are also consistent with the involvement of highly trace element enriched sources in the SCLM, such as stalled kimberlitic melts (Woodhead et al. 2019). Nitrogen systematics of the host diamonds appear consistent with young ages ( $<140 \mathrm{Ma})$ and yield high $T_{\mathrm{MR}}\left(1226-1246^{\circ} \mathrm{C}\right)$ suggesting deep formation or involvement of recent hot magmas. Stable isotope compositions (Fig. 2a, b) record a wide range in $\delta^{13} \mathrm{C}\left(-21.3 \%\right.$ to $-4.9 \%$ ) and $\delta^{15} \mathrm{~N}$ (7.5\% ; LK170 rim) suggesting the involvement of a wide variety of fluids and protoliths of crustal and mantle origin.

\section{Diamond formation beneath the Orapa cluster}

The $\mathrm{Sm}-\mathrm{Nd}$ isotope data demonstrate that the timing of websteritic diamond formation is simultaneous with eclogitic diamond formation at $2341 \pm 21,1110 \pm 64$, $220 \pm 80 \mathrm{Ma}$ and $<140 \mathrm{Ma}$ extending over an area of $\sim 200$ $\mathrm{km}^{2}$ beneath the Orapa cluster. The synchronous formation of E- and W-type diamonds on this scale places constraints on general diamond-forming processes. A fundamental question is whether a single metasomatic fluid 
was responsible for diamond formation on a regional scale (10's of km) or whether low-volume fluids were mobilised locally (on a scale of metres to kilometres) but contemporaneously in several locations (i.e., dispersed) across the Orapa cluster. Similar considerations were recently made by the authors (Gress et al. 2020) for the Jwaneng mine, $360 \mathrm{~km}$ southwest of the Orapa cluster. Metasomatic fluids derived from the asthenosphere or within the SCLM could have originated from peridotitic, websteritic or eclogitic sources. Such metasomatic sources may account for fluids of varying compositions when infiltrating the overlying lithosphere.

Websterites are commonly considered to be transitional between peridotites and eclogites, representing the result of fluid-rock interaction (Aulbach et al. 2002; Rapp et al. 1999). The geochemical systems involved in diamond petrogenesis can therefore be considered to have involved a minimum of three components (Fig. 8); peridotitic mantle (A); eclogites dominated by mafic material (B); and eclogites that included recycled sedimentary material (C). Simultaneous $\mathrm{W}$ - and E-type diamond formation would have produced compositional arrays as the diamond-forming metasomatic fluid(s) would have undergone fluid-rock reactions with different protoliths. Based on $\mathrm{C}-\mathrm{N}-\mathrm{O}-\mathrm{S}$ isotope heterogeneity in eclogitic xenoliths and E-type inclusions, previous workers have also argued for the evolution of metasomatic fluids (Deines and Harris 2004; Ickert et al. 2013; Smit et al. 2019; Thomassot et al. 2009). The inclusion chronology enables us to examine the inferred mixing processes and to assess any temporal variations (Figs. 7 and 8).

The P-type diamond component is the least well-constrained in this study. Although $\delta^{13} \mathrm{C}$ was not analysed for P-type samples LK058 and LK101 (>2.9 Ga), the garnet compositions (Fig. 3a) with low $\mathrm{Al} / \mathrm{Cr}(>1.5)$ overlap with the other P-type garnets from the Orapa cluster that have restricted $\mathrm{Al} / \mathrm{Cr}<6$ and $\delta^{13} \mathrm{C}$ between $-9.0 \%$ o to $-1.4 \%$ in the diamonds, typical for peridotitic mantle material ( $-5 \% \circ \pm 1 \%$; Cartigny et al. (2014)) i.e., component $\mathrm{A}$. The dated E-type garnets show a wide range in $\mathrm{Al} / \mathrm{Cr}$ ratios (100-1275), mantle residence temperatures $\left(T_{\mathrm{MR}} 1157-1246^{\circ} \mathrm{C}\right)$ and $\delta^{13} \mathrm{C}$ between -33.6 and $-4.2 \%$ (Fig. 8) in the diamonds. These data emphasise the broad range in $\mathrm{Fe}-\mathrm{Mg}$ equilibration temperatures $\left(1000-1480{ }^{\circ} \mathrm{C}\right.$ at $5 \mathrm{GPa}$ ) of co-genetic garnet and cpx at these locations (Deines et al. 1993; Motsamai et al. 2018). Hydrothermally altered subducted oceanic lithosphere is Al-rich and together with associated clastic and carbonate sediments, it represents component $\mathrm{B}$. This component, however, is only capable of explaining $\delta^{13} \mathrm{C}$ down to $\sim 24 \%$ ( $\mathrm{Li}$ et al. 2019). Thus, organic-rich material along with subducted oceanic lithosphere $\left(\delta^{13} \mathrm{C}<-24 \%\right.$ ) , i.e. component $\mathrm{C}$, is necessary to produce lighter $\delta^{13} \mathrm{C}$ compositions (Ickert et al. 2013). At Letlhakane, such light signatures are only present in $2.34 \mathrm{Ga}$ eclogitic diamonds (e.g. LK33). Covariation of light $\delta^{13} \mathrm{C}$ with positive $\delta^{15} \mathrm{~N}$ in the $2.34 \mathrm{Ga}$ LK42 and LK47 diamonds, typical for subducted (Archaean) sediments (Fig. 2a), implies a subduction origin as already suggested for Orapa (Cartigny et al. 1999; Chinn et al. 2018).

The dated $\mathrm{W}$-type inclusions have restricted $\mathrm{Al} / \mathrm{Cr}(<50)$ and light $\delta^{13} \mathrm{C}-25.7 \%$ to $-19.8 \%$ in the diamonds compared to the wide range in E-type diamonds. Despite the episodic growth history (Fig. 1g), adjacent growth zones in the websteritic diamonds record little carbon isotope variation $(<1.5 \%$; Online Resource 3$)$ and inclusions have similar parental fluid compositions (Fig. 5). Comparable $T_{\mathrm{MR}}$ and $T_{\mathrm{K}}$ demonstrate insignificant thermal impact from more recent diamond-forming events and are consistent with W-type diamond formation at depth of 140-180 km as suggested by Deines et al. (1993). In this setting, the carbon isotope compositions of different growth zones seem buffered by the local W-type protolith, suggesting carbon was (re-)mobilised under conditions of relatively low fluid/rock ratios.

The generation of the websteritic protolith must have occurred before $2.34 \mathrm{Ga}$ i.e., the age of the oldest websteritic diamond (LK338), and potentially involved organic-rich subducted material (component $\mathrm{C}$ ) mixing with mantle material (component A) because eclogitic $2.34 \mathrm{Ga}$ diamonds with low to moderate $\mathrm{Al} / \mathrm{Cr}(<600)$ and variable $\delta^{13} \mathrm{C}(-33.6$ to $-9.0 \%$ ) also fall along this hypothetical mixing array, as does the $>2.7 \mathrm{Ga}$ eclogitic garnet (Fig. 8). The REE enrichment of the inferred parental fluid compositions of these E- and W-type inclusions with the same age are consistent with a genetic link (Fig. 5).

The bi-modal $\delta^{13} \mathrm{C}$ distribution in eclogitic diamonds (Online Resource 1: Figure ESM_1.1) may be related to the involvement of different fluids (e.g., mantle vs recycled) and eclogitic protoliths which they infiltrate. Diamonds with lighter $\delta^{13} \mathrm{C}$ (mode at $-16.2 \%$ ) potentially have a common metasomatic fluid with the $\mathrm{W}$-type diamonds whose protoliths formed in the transition from the Archaean to the Paleoproterozoic. E-type diamonds with a mode at $-6.6 \%$ o represent mixtures of mantle component A with material predominantly derived from altered oceanic lithosphere (component B) that seem to represent the dominant source for E-type diamonds since the Mesoproterozoic. Simultaneous E- and W-type diamond formation was caused by fluids that migrated through different protoliths and were modified by local fluid/rock interaction. Depending on the prevailing buffering capacity of the protoliths (eclogite $>>$ websterite $>>$ peridotite) at specific times and depth (e.g., $\mathrm{fO}_{2}$; Burness et al. (2020); Woodland and Koch (2003)) the diamonds and inclusions would preferentially record component $\mathrm{A}$ mixed with either with component $\mathrm{B}$ or $\mathrm{C}$.

Due to insufficient data on mineral equilibration temperatures in our sample set, we cannot yet verify that Letlhakane diamonds with $\delta^{13} \mathrm{C}<-8 \%$ originate from a specific part 
Fig. 8 Time-dependant changes in $\mathrm{Al}_{2} \mathrm{O}_{3} / \mathrm{Cr}_{2} \mathrm{O}_{3}$ of garnet (square) and cpx (circle) inclusions versus the carbon isotope $\left(\delta^{13} \mathrm{C}\right.$ in \%o) composition of its corresponding diamond growth zone after Deines et al. (1993) and Deines et al. (2009). The figure illustrates estimated mixing trends between mantle (component A) with no crustal signature (low $\mathrm{Al}_{2} \mathrm{O}_{3} / \mathrm{Cr}_{2} \mathrm{O}_{3}$ and heavy $\delta^{13} \mathrm{C}(\sim-5.0 \% \circ \pm 1$ $\%$ o), hydrothermally altered subducted oceanic lithosphere (component $\mathrm{B}$ ) with variable amounts of Al- and Cr-oxide and $\delta^{13} \mathrm{C}(>-24 \%)$ and organic-rich material (component C) represented by LK33 with variable amounts of $\mathrm{Al}$ and $\mathrm{Cr}$-oxide and $\delta^{13} \mathrm{C}(<-24$ $\%$ ). Note: individual colours represent co-genetic inclusions, not dated samples from this study (grey fill), literature (white fill). Data sources as in Fig. 3
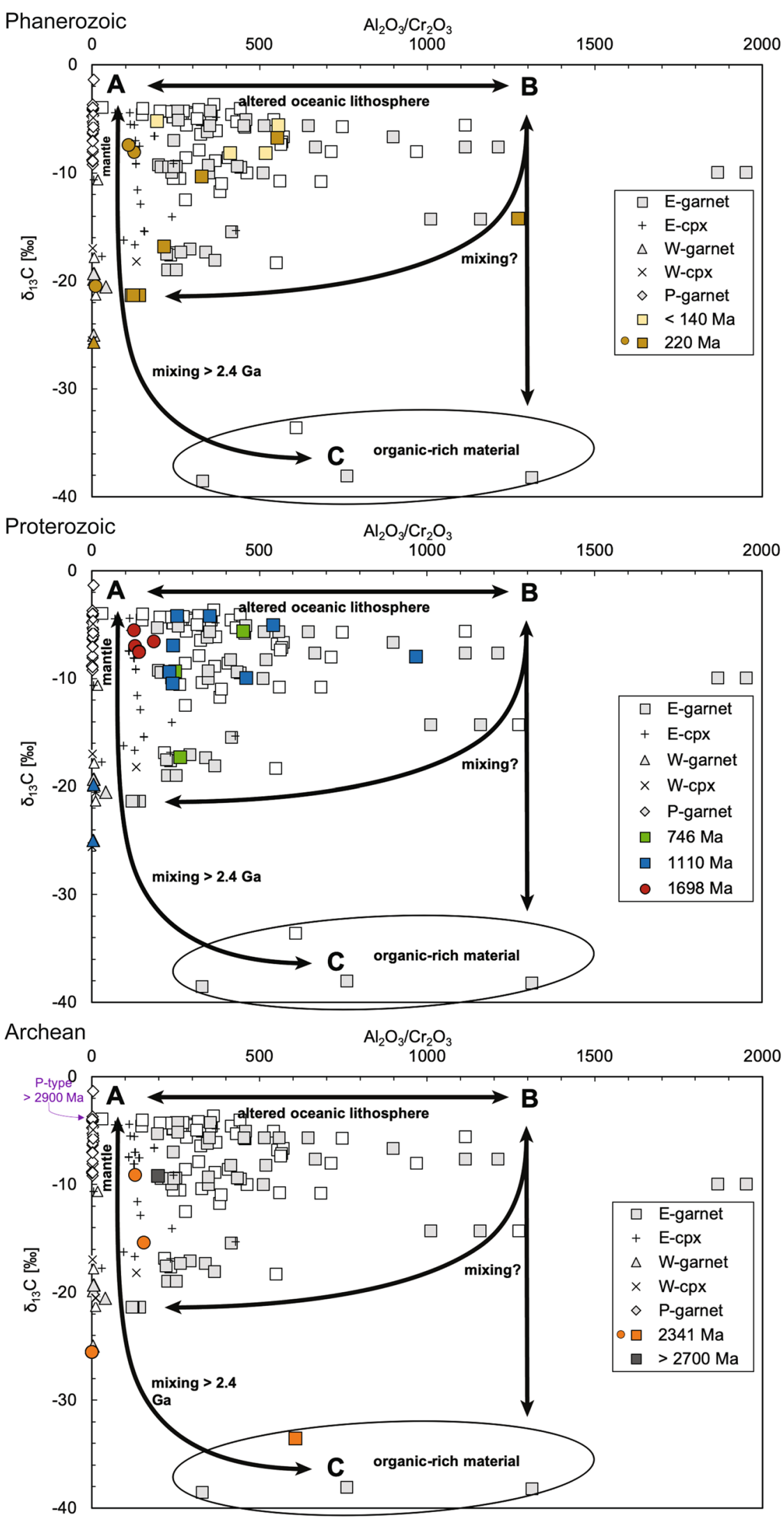
of the mantle $\left(1125-1240{ }^{\circ} \mathrm{C}\right.$ and depth of $\left.\sim 150-170 \mathrm{~km}\right)$ as suggested by Deines et al. (2009) but we can confirm W- and E-type diamond formation included a significant subducted organic-rich (Archaean) component. These observations support models that propose diamond growth under various redox conditions e.g., from oxidised $\mathrm{CO}_{2}$-/carbonate-bearing or reduced $\mathrm{CH}_{4}$-bearing fluids (Shirey et al. 2019), which complicates assessment of potential temporal changes in carbon sources.

\section{Implications for the deep carbon cycle}

Less than $20 \%$ of the studied diamonds have homogeneous $\mathrm{C}$ isotopes and N systematics (Online Resource 3) associated with oscillatory growth that may indicate formation within a geologically short period of time (millions of years; Bulanova et al. (2014)). The difference in $T_{\mathrm{MR}}\left(>100{ }^{\circ} \mathrm{C}\right)$ and the range in carbon isotopic composition and nitrogen content of these diamonds suggests that they are not all cogenetic and resided at different depths and conditions in the SCLM.

Some diamonds (e.g., LK241, LK272; Fig. 1b, e) record systematic variations in $\mathrm{C}$ isotopes and $\mathrm{N}$ systematics that could be ascribed to small changes in the conditions (P-T$\mathrm{fO}_{2}$ ) under which the diamonds precipitated (Boyd et al. 1992; Deines et al. 1989) while diamonds with abrupt compositional changes between major growth zones (Fig. 1f) clearly demonstrate formation of adjacent growth zones from different metasomatic fluids e.g., in LK09 $\delta^{13} \mathrm{C}$ varies from $-10.0 \%$ (core: $1110 \pm 64 \mathrm{Ma} ; T_{\mathrm{MR}}: 1109{ }^{\circ} \mathrm{C}$ ) to $-5.0 \%$ (rim). Review of the global dataset establishes that limited intra-diamond $\mathrm{C}$ isotope variation is typical (96\% have $<3 \%$ ) suggesting that the oxidation state and carbon speciation of diamond-forming fluids have been similar throughout history (Howell et al. 2020; Jablon and Navon 2016; Weiss et al. 2014). Local variations do exist, however, and, potentially in combination, changes in the scale and mechanism of diamond formation, may be depth or time dependent.

Based on his previous work, Deines et al. (2009) concluded that light $\delta^{13} \mathrm{C}$ values of bulk diamonds from the Orapa cluster were more prevalent with increasing mantle depth (> $200 \mathrm{~km})$. Depletion in LREE of the E- and W-type garnets (Fig. 4b, d) is similar to that found in eclogitic xenoliths from the base (170-220 km) of the Kalahari Craton while minerals from shallower levels $(140-180 \mathrm{~km})$ were found to be more LREE enriched (Burness et al. 2020). A $\delta^{13} \mathrm{C}$ depth dependence was also proposed at Argyle (Australia), where eclogitic diamonds with lighter carbon and lower ${ }^{3} \mathrm{He} /{ }^{4} \mathrm{He}$ ratios are mostly formed at the base of the lithosphere where subduction input is largest (Jaques et al. 1989; Timmerman et al. 2019).
A correlation of $\delta^{13} \mathrm{C}$ values with relative time has been proposed based on rim growth zones of diamonds that record heavier $\delta^{13} \mathrm{C}$ than their cores (Bulanova et al. 2014; Chinn et al. 2018; Thomson et al. 2014). Moreover, the internal range in $\delta^{13} \mathrm{C}$ values was found to become smaller (towards heavier values) in dated diamonds from 3.0 to 2.1 to $1.0 \mathrm{Ga}$ (Howell et al. 2020), indicating some homogenization of carbon isotope compositions in the SCLM. Globally, significant changes in $\delta^{13} \mathrm{C}$ values within individual diamonds (4\% has $>3 \%$ ) are rare (Howell et al. 2020). In contrast to this general trend, diamonds from Letlhakane have large internal shifts in $\delta^{13} \mathrm{C}$ values (33\% have $>3 \%$ ) and they predominantly (80\%) evolve towards heavier $\delta^{13} \mathrm{C}$ values from core to rim (Online Resource 2: Table ESM_2.3). This observation either supports a relative time-related dependence for the carbon isotope composition (Timmerman et al. 2017) and may indicate fluid input from a different part of the subducting slab and/or increasing input of carbonates with time or some homogenization of carbon in the SCLM (potentially restricted to a local scale) resulting in a higher relative sampling of heavier $\delta^{13} \mathrm{C}$ during diamond rim growth. In the latter case, the change of $\delta^{13} \mathrm{C}$ then is only dependent on the prevailing carbon composition of the local SCLM.

Overall, $\delta^{13} \mathrm{C}$ values of diamond hosts show no systematic variation with absolute inclusion age (Figs. 7 and 8). Largescale events in the region, such as the Bushveld Large Igneous Province (LIP) at $2.06 \mathrm{Ga}$ or Proterozoic crustal accretion such as the Rehoboth Terrain between 2.0 and $1.75 \mathrm{Ga}$ are capable of modifying major parts of the SCLM and may lead to a redistribution of volatile elements (Richardson and Shirey 2008). In this scenario, it appears that the observed variability in $\delta^{13} \mathrm{C}$ and inclusion composition in the studied diamonds has little systematic control and the deep carbon cycle seems controlled by a combination of time and protolith variability, which in turn may be partly depth controlled.

\section{Conclusions}

Eclogitic and websteritic silicate inclusion populations from Letlhakane record multiple and contemporary diamondforming events. In combination with inclusions from the nearby Orapa and Damtshaa mines, it is established that eclogitic and websteritic diamond formation occurred beneath the Orapa kimberlite cluster at $220 \pm 80 \mathrm{Ma}$, at $746 \pm 100 \mathrm{Ma}$, at $1110 \pm 64 \mathrm{Ma}$, at $1698 \pm 280 \mathrm{Ma}$ and at $2341 \pm 21 \mathrm{Ma}$ in events that are related to major tectonomagmatic perturbations in the SCLM (see Online Resource 1 for greater discussion). Additionally, two less-well-defined events close to kimberlite eruption $(<140 \mathrm{Ma})$ and during craton stabilisation $(>2.7 \mathrm{Ga})$ can be established. Harzburgitic diamond formation in the roots of the SCLM also 
occurred at this time $(\geq 2.9 \mathrm{Ga})$ stressing a multitude of discrete diamond genesis regimes.

The majority $(80 \%)$ of the diamonds show complex growth histories in their CL images, FTIR data and C-N isotopes confirming a multi-stage evolution, while the remaining diamonds may have formed in single events. Websteritic diamonds appear to have formed in a relatively confined part of the mantle and subsequent tectonomagmatic events potentially triggered diamond formation through (re-)mobilisation of material. The simultaneous formation of E- and W-type diamonds further emphasises a local control of the diamond-forming protolith over the fluid and implies generally low fluid/rock ratios during E and W-type diamond growth. Formation of the metasomatic fluid was triggered by large-scale tectono-magmatic events that affected major portions of the SCLM. The REE contents of inclusions together with the observed range in carbon isotopes of the growth zones suggest that this variation in the deep carbon cycle is related to the heterogeneity of the SCLM that evolved over time rather than a change in the nature of the subducted material that was transferred into the SCLM over the past 3 Gyrs.

Supplementary Information The online version contains supplementary material available at https://doi.org/10.1007/s00410-021-01802-8.

Acknowledgements The authors sincerely thank Debswana and De Beers for providing access to run of mine production at DTCB and the generous supply of diamonds. MUG was funded through NWO project 824.14.004 (awarded to GRD) and for one year by De Beers Group Services. Carbon isotope analyses were partly funded by Europlanet 2020 RI that received funding from the European Union's Horizon 2020 research and innovation programme under grant agreement No 654208. The analytical development of high-resolution C- and N- isotope measurement by LG-SIMS greatly benefit from technical discussion with Johan Villeneuve. ET thanks Dorrit Jacob and Daniel Howell for generous supply of the reference material to aid development of high-resolution $\mathrm{C}$ and $\mathrm{N}$ isotope analyses at CRPG-Nancy. MUG also gratefully acknowledges Karen V. Smit and Wuyi Wang, Gemological Institute of America, for access to perform additional FTIR analyses during an internship realised through the American Immigration Council. Richard Smeets, Suzan Verdegaal-Warmerdam, Bouke Lacet, Ciaran Kelly, Peter van Krieken, Sergei Matveev and Tilly Bouten are thanked for assistance with analyses. Pieter Ouwerkerk and Gassan Diamond B.V. is thanked for help with polishing. The Dr. Schürmannfonds foundation provided support for field work to Botswana during which sample selection was made with support of Quint van den Heuvel, Ellen Schulten and Cas Nooitgedacht. Thomas Stachel is thanked for providing access to the De Beers diamond laboratory at the University of Alberta, Edmonton, for FTIR analyses. The manuscript benefitted from constructive comments of Stephen Richardson, an anonymous reviewer and editor Dante Canil.

Open Access This article is licensed under a Creative Commons Attribution 4.0 International License, which permits use, sharing, adaptation, distribution and reproduction in any medium or format, as long as you give appropriate credit to the original author(s) and the source, provide a link to the Creative Commons licence, and indicate if changes were made. The images or other third party material in this article are included in the article's Creative Commons licence, unless indicated otherwise in a credit line to the material. If material is not included in the article's Creative Commons licence and your intended use is not permitted by statutory regulation or exceeds the permitted use, you will need to obtain permission directly from the copyright holder. To view a copy of this licence, visit http://creativecommons.org/licenses/by/4.0/.

\section{References}

Allsopp H, Bristow J, Smith C, Brown R, Gleadow A, Kramers J, Garvie O (1989) A summary of radiometric dating methods applicable to Kimberlites and related rocks. Kimberlites and Related Rocks 1:343-357

Aulbach S, Creaser RA, Stachel T, Heaman LM, Chinn IL, Kong J (2018) Diamond ages from Victor (Superior Craton): intramantle cycling of volatiles $(\mathrm{C}, \mathrm{N}, \mathrm{S})$ during supercontinent reorganisation. Earth Planet Sc Lett 490:77-87

Aulbach S, Jacob DE (2016) Major- and trace-elements in cratonic mantle eclogites and pyroxenites reveal heterogeneous sources and metamorphic processing of low-pressure protoliths. Lithos 262:586-605

Aulbach S, Stachel T, Viljoen SK, Brey GP, Harris JW (2002) Eclogitic and websteritic diamond sources beneath the Limpopo Belt-is slab-melting the link? Contrib Mineral Petr 143:56-70

Barth MG, Rudnick RL, Horn I, McDonough WF, Spicuzza MJ, Valley JW, Haggerty SE (2001) Geochemistry of xenolithic eclogites from West Africa Part I: a link between low $\mathrm{MgO}$ eclogites and archean crust formation. Geochim Cosmochim Acta 65:1499-1527

Bodinier J-L, Garrido CJ, Chanefo I, Bruguier O, Gervilla F (2008) Origin of pyroxenite-peridotite veined mantle by refertilization reactions: evidence from the Ronda peridotite (Southern Spain). J Petrol 49:999-1025

Bouden $\mathrm{N}$ et al (2021) Triple oxygen isotope measurements by multicollector secondary ion mass spectrometry. Front Earth Sci 8:601169

Boyd S, Kiflawi I, Woods G (1994) The relationship between infrared absorption and the a defect concentration in diamond. Philos Mag B 69:1149-1153

Boyd S, Pillinger C, Milledge H, Mendelssohn M, Seal M (1992) C and $\mathrm{N}$ isotopic composition and the infrared absorption spectra of coated diamonds: evidence for the regional uniformity of $\mathrm{CO} 2 \mathrm{H} 2 \mathrm{O}$ rich fluids in lithospheric mantle. Earth Planet Sc Lett 109:633-644

Branchetti M, Zepper JC, Peters ST, Koornneef JM, Davies GR (2021) Multi-stage garnet formation and destruction in Kimberley harzburgitic xenoliths, South Africa. Lithos 106119

Brookes E, Comins J, Daniel R, Erasmus R (2000) A study of plastic deformation profiles of impressions in diamond. Diam Relat Mater 9:1115-1119

Bulanova G, de Vries DW, Pearson D, Beard A, Mikhail S, Smelov A, Davies G (2014) An eclogitic diamond from Mir pipe (Yakutia), recording two growth events from different isotopic sources. Chem Geol 381:40-54

Burness S, Smart K, Tappe S, Stevens G, Woodland A, Cano E (2020) Sulphur-rich mantle metasomatism of Kaapvaal craton eclogites and its role in redox-controlled platinum group element mobility. Chem Geol 119476

Carlson R, Pearson D, Boyd F, Shirey S, Irvine G, Menzies A, Gurney J Re-Os systematics of lithospheric peridotites: implications for lithosphere formation and preservation. In: Proceedings of the 7th international Kimberlite conference, 1999. Red Roof Design Cape Town, pp 99-108

Cartigny P, Harris J, Javoy M (1999) Eclogitic, peridotitic and metamorphic diamonds and the problems of carbon recycling - the 
case of Orapa (Botswana). In: The JB Dawson volume-proceedings of the seventh international kimberlite conference, Cape Town. Red Roof Design, Cape Town. pp 117-124

Cartigny P, Harris JW, Javoy M (1998) Eclogitic diamond formation at Jwaneng: no room for a recycled component. Science 280:1421-1424. https://doi.org/10.1126/science.280.5368. 1421

Cartigny P, Harris JW, Javoy M (2001) Diamond genesis, mantle fractionations and mantle nitrogen content: a study of $\delta 13 \mathrm{C}-\mathrm{N}$ concentrations in diamonds. Earth Planet Sc Lett 185:85-98

Cartigny P, Palot M, Thomassot E, Harris JW (2014) Diamond formation: a stable isotope perspective. Annu Rev Earth Planet Sci 42:699-732

Cartigny P, Stachel T, Harris JW, Javoy M (2004) Constraining diamond metasomatic growth using $\mathrm{C}$-and $\mathrm{N}$-stable isotopes: examples from Namibia. Lithos 77:359-373

Chinn IL, Perritt SH, Stiefenhofer J, Stern RA (2018) Diamonds from Orapa Mine show a clear subduction signature in SIMS stable isotope data. Mineral Petrol 112:197-207

Clark C, Davey S (1984) Defect-induced one-phonon absorption in type Ia diamonds. J Phys C 17:L399

Collins AT (1992) The characterisation of point defects in diamond by luminescence spectroscopy. Diam Relat Mater 1:457-469

Davis GL (1977) The ages and uranium contents of zircons from kimberlites and associated rocks. In: International Kimberlite Conference: Extended Abstracts. pp 67-69

Deines P (1980) The carbon isotopic composition of diamonds: relationship to diamond shape, color, occurrence and vapor composition. Geochim Cosmochim Ac 44:943-961

Deines P, Gurney JJ, Harris JW (1984) Associated chemical and carbon isotopic composition variations in diamonds from Finsch and Premier kimberlite, South Africa. Geochim Cosmochim Acta 48:325-342

Deines P, Harris J, Gurney J (1997) Carbon isotope ratios, nitrogen content and aggregation state, and inclusion chemistry of diamonds from Jwaneng, Botswana. Geochim Cosmochim Acta 61:3993-4005

Deines P, Harris JW (2004) New insights into the occurrence of $13 \mathrm{C}$-depleted carbon in the mantle from two closely associated kimberlites: Letlhakane and Orapa Botswana. Lithos 77:125-142

Deines P, Harris JW, Gurney JJ (1993) Depth-related carbon isotope and nitrogen concentration variability in the mantle below the Orapa kimberlite Botswana, Africa. Geochim Cosmochim Acta 57:2781-2796

Deines P, Harris JW, Spear PM, Gurney JJ (1989) Nitrogen and 13C content of Finsch and Premier diamonds and their implications. Geochim Cosmochim Acta 53:1367-1378

Deines P, Stachel T, Harris JW (2009) Systematic regional variations in diamond carbon isotopic composition and inclusion chemistry beneath the Orapa kimberlite cluster, in Botswana. Lithos 112:776-784

Dischler B (2012) Handbook of spectral lines in diamond: volume 1: tables and interpretations, vol 1. Springer, New York

Farquhar J, Wing B, McKeegan K, Harris J, Cartigny P, Thiemens M (2002) Mass-independent sulfur of inclusions in diamond and sulfur recycling on early. Earth Sci 298:2369-2372

Fraser K, Hawkesworth C, Erlank A, Mitchell R, Scott-Smith B (1985) $\mathrm{Sr}, \mathrm{Nd}$ and $\mathrm{Pb}$ isotope and minor element geochemistry of lamproites and kimberlites. Earth Planet Sci Lett 76:57-70

Galimov E (1991) Isotope fractionation related to kimberlite magmatism and diamond formation. Geochim Cosmochim Acta 55:1697-1708

Gress MU et al (2018) Episodic diamond growth beneath the Kaapvaal Craton at Jwaneng Mine, Botswana. Mineral Petrol 112:219-229
Gress MU, Koornneef JM, Thomassot E, Chinn IL, van Zuilen K, Davies GR (2020) Sm-Nd isochron ages coupled with CN isotope data of eclogitic diamonds from Jwaneng, Botswana. Geochim Cosmochim Acta 293:1-17

Gress MU, Pearson DG, Chinn IL, Thomassot E, Davies GR (2021) Mesozoic to Paleoproterozoic diamond growth beneath Botswana recorded by Re-Os ages from individual eclogitic and websteritic inclusions. Lithos 388:106058

Griffin W, O'Reilly SY, Natapov L, Ryan C (2003) The evolution of lithospheric mantle beneath the Kalahari Craton and its margins. Lithos 71:215-241

Griffin W, Shee S, Ryan C, Win T, Wyatt B (1999) Harzburgite to lherzolite and back again: metasomatic processes in ultramafic xenoliths from the Wesselton kimberlite Kimberley, South Africa. Contrib Mineral Petr 134:232-250

Grütter HS, Gurney JJ, Menzies AH, Winter F (2004) An updated classification scheme for mantle-derived garnet, for use by diamond explorers. Lithos 77:841-857

Grütter HS, Latti D, Menzies A (2006) Cr-saturation arrays in concentrate garnet compositions from kimberlite and their use in mantle barometry. J Petrol 47:801-820

Gurney J, Harris JW, Rickard RS (1984) Silicate and oxide inclusions in diamonds from the Orapa Mine, Botswana Kimberlites II: the mantle and crust-mantle relationships. Elsevier, Amsterdam, pp 3-9

Gurney J, Helmstaedt H, Richardson S, Shirey S (2010) Diamonds through Time. Econom Geol 105:689-712

Harte B, Kirkley MB (1997) Partitioning of trace elements between clinopyroxene and garnet: data from mantle eclogites. Chem Geol 136:1-24

Howell D et al (2020) Deep carbon through time: earth's diamond record and its implications for carbon cycling and fluid speciation in the mantle. Geochim Cosmochim Acta 275:99-122

Ickert R, Stachel T, Stern R, Harris J (2013) Diamond from recycled crustal carbon documented by coupled $\delta 18 \mathrm{O}-\delta 13 \mathrm{C}$ measurements of diamonds and theirinclusions. Earth Planet Sci Lett 364:85-97

Jablon BM, Navon O (2016) Most diamonds were created equal. Earth Planet Sci Lett 443:41-47

Jacobsen SB, Wasserburg G (1980) Sm-Nd isotopic evolution of chondrites. Earth Planet Sci Lett 50:139-155

Jaques A, Sun S, Chappell B (1989) Geochemistry of the Argyle (AK1) lamproite pipe, Western Australia Geological Society of Australia Special Publication. 14:e188

Javoy M, Pineau F, Delorme H (1986) Carbon and nitrogen isotopes in the mantle. Chem Geol 57:41-62

Kessel R, Schmidt MW, Ulmer P, Pettke T (2005) Trace element signature of subduction-zone fluids, melts and supercritical liquids at $120-180 \mathrm{~km}$ depth. Nature 437:724

Kohn SC, Speich L, Smith CB, Bulanova GP (2016) FTIR thermochronometry of natural diamonds: a closer look. Lithos 265:148-158

Koornneef JM, Gress MU, Chinn IL, Jelsma HA, Harris JW, Davies GR (2017) Archaean and proterozoic diamond growth from contrasting styles of large-scale magmatism. Nat Commun 8:648. https://doi.org/10.1038/s41467-017-00564-x

Leahy K, Taylor W (1997) The influence of the Glennie domain deep structure on the diamonds in Saskatchewan kimberlites. Geol Geofiz 38:451-460

Li K, Li L, Pearson DG, Stachel T (2019) Diamond isotope compositions indicate altered igneous oceanic crust dominates deep carbon recycling. Earth Planet Sc Lett 516:190-201

Michard A, Gurriet P, Soudant M, Albarede F (1985) Nd isotopes in French Phanerozoic shales: external vs. internal aspects of crustal evolution. Geochim Cosmochim Acta 49:601-610 
Mitchell RH (1986) The nature of kimberlites. In: International Kimberlite Conference: Extended Abstracts. pp 9-11

Morimoto N et al (1988) Nomenclature of pyroxenes. Am Miner 73:1123-1133

Motsamai T, Harris JW, Stachel T, Pearson DG, Armstrong J (2018) Mineral inclusions in diamonds from Karowe Mine, Botswana: super-deep sources for super-sized diamonds? Mineral Petrol 112:169-180

O'Reilly SY, Griffin W (1995) Trace-element partitioning between garnet and clinopyroxene in mantle-derived pyroxenites and eclogites: PTX controls. Chem Geol 121:105-130

Pearson DG, Harris JW (2004) Age constraints for diamonds from Koffiefontein mine, S Africa, a Re-Os Isotope and N-Aggregation. Study Age 5:21

Pearson DG, Shirey S, Bulanova G, Carlson R, Milledge H (1999) $\mathrm{Re}-\mathrm{Os}$ isotope measurements of single sulfide inclusions in a siberian diamond and its nitrogen aggregation systematics. Geochim Cosmochim Acta 63:703-711

Pearson DG, Shirey S, Harris J, Carlson R (1998) Sulphide inclusions in diamonds from the Koffiefontein kimberlite, S Africa: constraints on diamond ages and mantle Re-Os systematics. Earth Planet Sci Lett 160:311-326

Pearson DG, Woodhead J, Janney PE (2019) Kimberlites as geochemical probes of Earth's mantle elements: an International Magazine of Mineralogy. Geochemy Petrol 15:387-392

Rapp R, Shimizu N, Norman M, Applegate G (1999) Reaction between slab-derived melts and peridotite in the mantle wedge: experimental constraints at $3.8 \mathrm{GPa}$. Chem Geol 160:335-356

Richardson SH, Gurney JJ, Erlank AJ, Harris JW (1984) Origin of diamonds in old enriched mantle. Nature 310:198-202

Richardson SH, Shirey S, Harris J, Carlson R (2001) Archean subduction recorded by $\mathrm{Re}-\mathrm{Os}$ isotopes in eclogitic sulfide inclusions in Kimberley diamonds. Earth Planet Sci Lett 191:257-266

Richardson SH, Shirey SB (2008) Continental mantle signature of Bushveld magmas and coeval diamonds. Nature 453:910-913

Richardson SH, Shirey SB, Harris JW (2004) Episodic diamond genesis at Jwaneng, Botswana, and implications for Kaapvaal craton evolution. Lithos 77:143-154

Schrauder M, Koeberl C, Navon O (1996) Trace element analyses of fluid-bearing diamonds from Jwaneng, Botswana. Geochim Cosmochim Acta 60:4711-4724

Schulze DJ, Harte B, Valley JW, Brenan JM, Dominic MDR (2003) Extreme crustal oxygen isotope signatures preserved in coesite in diamond. Nature 423:68-70

Shirey SB et al (2002) Diamond genesis, seismic structure, and evolution of the Kaapvaal-Zimbabwe craton. Science 297:1683-1686

Shirey SB, Richardson SH (2011) Start of the Wilson cycle at 3 Ga shown by diamonds from subcontinental mantle. Science 333:434-436. https://doi.org/10.1126/science.1206275

Shirey SB, Richardson SH, Harris JW (2008) Mesoarchean to Mesoproterozoic Re-Os ages for sulfide inclusions in Orapa diamonds and implications for Kaapvaal-Zimbabwe craton development. In: International Kimberlite Conference: Extended Abstracts.

Shirey SB et al. (2019) Diamonds and the mantle geodynamics of carbon deep carbon

Simon NSC, Carlson RW, Pearson DG, Davies GR (2007) The origin and evolution of the Kaapvaal cratonic lithospheric mantle. J Petrol 48:589-625

Sleep NH (2006) Mantle plumes from top to bottom. Earth Sci Rev 77:231-271

Smart KA, Chacko T, Stachel T, Muehlenbachs K, Stern RA, Heaman LM (2011) Diamond growth from oxidized carbon sources beneath the Northern Slave Craton, Canada: a $\delta 13 \mathrm{C}-\mathrm{N}$ study of eclogite-hosted diamonds from the Jericho kimberlite. Geochim Cosmochim Acta 75:6027-6047
Smit KV, Pearson DG, Stachel T, Seller M (2014) Peridotites from Attawapiskat, Canada: mesoproterozoic reworking of palaeoarchaean lithospheric mantle beneath the northern superior superterrane. J Petrol 55:1829-1863

Smit KV, Shirey SB, Wang W (2016) Type Ib diamond formation and preservation in the West African lithospheric mantle: Re-Os age constraints from sulphide inclusions in Zimmi diamonds. Precambrian Res 286:152-166

Smit KV, Stachel T, Luth RW, Stern RA (2019) Evaluating mechanisms for eclogitic diamond growth: an example from Zimmi Neoproterozoic diamonds (West African craton). Chem Geol 520:21-32

Sobolev N, Snyder GA, Taylor LA, Keller RA, Yefimova ES, Sobolev VN, Shimizu N (1998) Extreme chemical diversity in the mantle during eclogitic diamond formation: evidence from 35 garnet and 5 pyroxene inclusions in a single diamond. Int Geol Rev 40:567-578

Stachel T, Aulbach S, Brey GP, Harris JW, Leost I, Tappert R, Viljoen KF (2004a) The trace element composition of silicate inclusions in diamonds: a review. Lithos 77:1-19

Stachel T, Brey GP, Harris JW (2005) Inclusions in sublithospheric diamonds: glimpses of deep. Earth Elements 1:73-78

Stachel T, Harris JW (2008) The origin of cratonic diamonds-constraints from mineral inclusions. Ore Geol Rev 34:5-32

Stachel T, Viljoen K, McDade P, Harris J (2004b) Diamondiferous lithospheric roots along the western margin of the Kalahari Craton-the peridotitic inclusion suite in diamonds from Orapa and Jwaneng. Contrib Mineral Petr 147:32-47

Stiefenhofer J, Viljoen K, Marsh J (1997) Petrology and geochemistry of peridotite xenoliths from the Letlhakane kimberlites, Botswana. Contrib Mineral Petr 127:147-158

Taylor LA, Anand M, Promprated P (2003) Diamonds and their inclusions: are the criteria for syngenesis valid. In: 8th International Kimberlite Conference. Long Abstract, Victoria, Canada

Taylor W, Jaques A, Ridd M (1990) Nitrogen-defect aggregation characteristics of some Australasian diamonds: time-temperature constraints on the source regions of pipe and alluvial diamonds. Am Miner 75:1290-1310

Thomassot E, Cartigny P, Harris J, Lorand J, Rollion-Bard C, Chaussidon M (2009) Metasomatic diamond growth: a multi-isotope study $(13 \mathrm{C}, 15 \mathrm{~N}, 33 \mathrm{~S}, 34 \mathrm{~S})$ of sulphide inclusions and their host diamonds from Jwaneng (Botswana). Earth Planet Sci Lett 282:79-90

Thomassot E, Cartigny P, Harris J, Viljoen KF (2007) Methane-related diamond crystallization in the earth's mantle: stable isotope evidences from a single diamond-bearing xenolith. Earth Planet Sci Lett 257:362-371

Thomson A, Kohn S, Bulanova G, Smith C, Araujo D, Walter M (2014) Origin of sub-lithospheric diamonds from the Juina-5 kimberlite (Brazil): constraints from carbon isotopes and inclusion compositions. Contrib Mineral Petr 168:1081

Timmerman S, Chinn IL, Fisher D, Davies GR (2018) Formation of unusual yellow Orapa diamonds. Mineral Petrol 112:209-218

Timmerman S, Koornneef JM, Chinn IL, Davies GR (2017) Dated eclogitic diamond growth zones reveal variable recycling of crustal carbon through time. Earth Planet Sci Lett 463:178-188

Timmerman S, Krebs MY, Pearson DG, Honda M (2019) Diamondforming media through time-Trace element and noble gas systematics of diamonds formed over 3 billion years of Earth's history. Geochim Cosmochim Acta 257:266-283

Timmerman S, Matveev S, Gress MU, Davies GR (2015) A methodology for wavelength dispersive electron probe microanalysis of unpolished silicate minerals. J Geochem Explor 159:243-251

van Wyk J (1982) Carbon-13 hyperfine interaction of the unique carbon of the P2 (ESR) or N3 (optical) centre in diamond 
Varma C (1970) Some observations on the reported evidence of slip during growth of natural diamond crystals. Acta Metall 18:1113-1119

Viljoen K, Perritt S, Chinn I (2018) An unusual suite of eclogitic, websteritic and transitional websteritic-lherzolitic diamonds from the Voorspoed kimberlite in South Africa: mineral inclusions and infrared characteristics. Lithos 320:416-434

Weiss Y, Griffin W, Navon O (2013) Diamond-forming fluids in fibrous diamonds: the trace-element perspective. Earth Planet Sci Lett 376:110-125

Weiss Y, Kiflawi I, Davies N, Navon O (2014) High-density fluids and the growth of monocrystalline diamonds. Geochim Cosmochim Acta 141:145-159

Welbourn C, Cooper M, Spear P (1996) De Beers natural versus synthetic diamond verification instruments. Gems Gemol 32

Westerlund K, Gurney J, Carlson R, Shirey S, Hauri E, Richardson $S$ (2004) A metasomatic origin for late Archean eclogitic diamonds: implications from internal morphology of diamonds and $\mathrm{Re}-\mathrm{Os}$ and $\mathrm{S}$ isotope characteristics of their sulfide inclusions from the late Jurassic Klipspringer kimberlites. S Afr J Geol 107:119-130

Wiggers de Vries D, Pearson DG, Bulanova G, Smelov A, Pavlushin A, Davies G (2013) Re-Os dating of sulphide inclusions zonally distributed in single Yakutian diamonds: evidence for multiple episodes of Proterozoic formation and protracted timescales of diamond growth. Geochim Cosmochim Acta 120:363-394

Woodhead J, Hergt J, Giuliani A, Maas R, Phillips D, Pearson DG, Nowell G (2019) Kimberlites reveal 2.5-billion-year evolution of a deep, isolated mantle reservoir. Nature 573:578-581

Woodland AB, Koch M (2003) Variation in oxygen fugacity with depth in the upper mantle beneath the Kaapvaal craton Southern Africa. Earth Planet Sci Lett 214:295-310

Yu X, Raterron P, Zhang J, Lin Z, Wang L, Zhao Y (2012) Constitutive law and flow mechanism in diamond deformation. Sci Rep 2:1-7

Publisher's Note Springer Nature remains neutral with regard to jurisdictional claims in published maps and institutional affiliations. 